\title{
Selective Disruption of Metabotropic Glutamate Receptor 5-Homer Interactions Mimics Phenotypes of Fragile X Syndrome in Mice
}

\author{
Weirui Guo, ${ }^{1 \star}$ Gemma Molinaro, ${ }^{1 \star}$ Katie A. Collins,,${ }^{1 *}$ (DSeth A. Hays, ${ }^{1}$ Richard Paylor, ${ }^{3}$ Paul F. Worley, ${ }^{4}$ \\ Karen K. Szumlinski, ${ }^{2}$ and Kimberly M. Huber ${ }^{1}$ \\ ${ }^{1}$ University of Texas Southwestern Medical Center, Department of Neuroscience, Dallas, Texas 75390, ${ }^{2}$ Department of Psychological and Brain Sciences, \\ Neuroscience Research Institute, University of California, Santa Barbara, California 93106, ${ }^{3}$ Department of Molecular and Human Genetics, Baylor College \\ of Medicine, Houston, Texas 77030, and ${ }^{4}$ Solomon H. Snyder Department of Neuroscience, Johns Hopkins University School of Medicine, Baltimore,
} Maryland 21205

Altered function of the Gq-coupled, Group 1 metabotropic glutamate receptors, specifically mGlu5, is implicated in multiple mouse models of autism and intellectual disability. mGlu 5 dysfunction has been most well characterized in the fragile X syndrome mouse model, the Fmr1 knock-out (KO) mouse, where pharmacological and genetic reduction of mGlu5 reverses many phenotypes. mGlu5 is less associated with its scaffolding protein Homer in Fmr1 KO mice, and restoration of mGlu5-Homer interactions by genetic deletion of a short, dominant negative of Homer, H1a, rescues many phenotypes of Fmrl KO mice. These results suggested that disruption of mGlu5Homer leads to phenotypes of FXS. To test this idea, we examined mice with a knockin mutation of mGlu5 (F1128R; mGlu $\left.5^{R / R}\right)$ that abrogates binding to Homer. Although FMRP levels were normal, mGlu $5^{R / R}$ mice mimicked multiple phenotypes of Fmr1 KO mice, including reduced mGlu5 association with the postsynaptic density, enhanced constitutive mGlu5 signaling to protein synthesis, deficits in agonist-induced translational control, protein synthesis-independent LTD, neocortical hyperexcitability, audiogenic seizures, and altered behaviors, including anxiety and sensorimotor gating. These results reveal new roles for the Homer scaffolds in regulation of mGlu5 function and implicate a specific molecular mechanism in a complex brain disease.

Key words: fragile X syndrome; Homer; LTD; mGluR5; protein synthesis; UP states

Significance Statement

Abnormal function of the metabotropic, or Gq-coupled, glutamate receptor 5 (mGlu5) has been implicated in neurodevelopmental disorders, including a genetic cause of intellectual disability and autism called fragile X syndrome. In brains of a mouse model of fragile $\mathrm{X}, \mathrm{mGlu} 5$ is less associated with its binding partner Homer, a scaffolding protein that regulates mGlu5 localization to synapses and its ability to activate biochemical signaling pathways. Here we show that a mouse expressing a mutant mGlu5 that cannot bind to Homer is sufficient to mimic many of the biochemical, neurophysiological, and behavioral symptoms observed in the fragile $\mathrm{X}$ mouse. This work provides strong evidence that Homer-mGlu5 binding contributes to symptoms associated with neurodevelopmental disorders.

\section{Introduction}

Altered function of Group1 metabotropic glutamate receptors, mGlu 1 and mGlu5, is increasingly implicated in mouse models of

\footnotetext{
Received Aug. 3, 2015; revised Dec. 16, 2015; accepted Jan. 5, 2016.

Author contributions: W.G., G.M., K.A.C., S.A.H., R.P., P.F.W., K.K.S., and K.M.H. designed research; W.G., G.M., K.A.C., S.A.H., R.P., and K.K.S. performed research; P.F.W. contributed unpublished reagents/analytic tools; W.G., G.M., K.A.C., S.A.H., R.P., K.K.S., and K.M.H. analyzed data; K.A.C., K.K.S., and K.M.H. wrote the paper.

This work was supported by National Institutes of Health Grants R01-NS045711 to K.M.H. and R.P., DA024038 to K.K.S., and T32-NS069562 to K.A.C., and FRAXA Research Foundation to W.G. We thank Nicole Cabalo, Maria Diosdado, Cindy M. Reyes, and Alexis W. Ary for technical assistance with the mice.

The authors declare no competing financial interests.
}

neurodevelopmental disorders, autism, and intellectual disability (Auerbach et al., 2011; Michalon et al., 2012; Ebrahimi-Fakhari and Sahin, 2015; Tian et al., 2015). Enhanced function of mGlu5 is most strongly linked to the etiology of fragile $\mathrm{X}$ syndrome (FXS), a leading monogenic cause of intellectual disability and autism that results from loss of function mutations in the RNA

\section{*W.G., G.M., and K.A.C. contributed equally to this study.}

Correspondence should be addressed to Dr. Kimberly M. Huber, University of Texas, Southwestern Medical Center, Department of Neuroscience, Box 9111, Dallas, TX 75390-9111. E-mail: Kimberly.Huber@UTSouthwestern.edu. DOI:10.1523/JNEUROSCI.2921-15.2016

Copyright $\odot 2016$ the authors $\quad 0270-6474 / 16 / 362131-17 \$ 15.00 / 0$ 
binding protein, FMRP (Darnell and Klann, 2013). Antagonism of mGlu5 is therapeutic for FXS in fly and mouse models (Michalon et al., 2012) and, therefore, is a candidate therapeutic for humans with FXS (Scharf et al., 2015). Enhanced mGlu5 function in the FXS mouse model, Fmr1 knock-out (KO) mouse, is manifest as hyperactivity of signaling pathways, elevated protein synthesis rates, hyperexcitability of cortical circuits, and seizures that are all reversed by genetic reduction or antagonism of mGlu5 (Dölen et al., 2007; Michalon et al., 2012). In addition to elevated "basal" activity of mGlu5, Fmr1 KO neurons do not respond to agonist stimulation, suggesting that mGlu5 signaling pathways are saturated or mGlu5 is uncoupled from effectors (Gross et al., 2010; Sharma et al., 2010; Ronesi et al., 2012).

A candidate molecular mechanism for mGlu5 dysfunction in FXS is decreased association of mGlu 5 with the Homer family of scaffolding proteins (Giuffrida et al., 2005; Ronesi et al., 2012). The N-terminal EVH1 domain of Homers binds to a proline-rich motif in the intracellular C terminus of mGlul $\alpha$ and mGlu5. The so-called, "long" forms of Homer (Homer1, 2, 3) form a tetrameric complex through C-terminal coiled-coil domains, cluster mGlu1/5 in the membrane, and scaffold mGlu1/5 to their effectors through other Homer binding proteins, such as phospholipase C $\beta$, PI3K enhancer (PIKE), IP3 receptor, Shank, TrpC channels, and others (Shiraishi-Yamaguchi and Furuichi, 2007; Worley et al., 2007). In contrast, Homerla (H1a), a "short," activity-inducible isoform of Homer1, lacks the coiled-coil domain and, therefore, does not form a multimeric complex with other Homers. H1a competes with "long" Homers for binding to mGlu1/5 and disrupts mGlu5 scaffolding with other Homer binding proteins (Shiraishi-Yamaguchi and Furuichi, 2007; Szumlinski et al., 2008). mGlu5 that is not in a long-Homer scaffold, either as a result of H1a overexpression or a specific mutation in the Homer binding site (mGlu5F1128R), results in agonist-independent, or constitutive, activity of the receptor (Ango et al., 2001). In Fmr1 KO mice forebrain, mGlu5 is less associated with long Homers and more associated with H1a (Giuffrida et al., 2005) and, therefore, may be constitutively active and not appropriately scaffolded to its effectors. Disrupted mGlu5/Homer may underlie the altered mGlu5 function and phenotypes of FXS. In support of this hypothesis, genetic deletion of $\mathrm{Hla}$ restored normal mGlu5-long Homer association in Fmr1 $\mathrm{KO}$ mice and corrected much of the mGlu5 dysfunction as well as behavioral phenotypes, such as anxiety and audiogenic seizures (Ronesi et al., 2012).

Although genetic deletion of H1a rescues Fmr1 KO phenotypes, it is unclear whether a specific disruption of Homer and mGlu5 is sufficient to mediate FXS-related phenotypes. To test this idea, we examined a mouse with a knockin of mGlu5 harboring a single amino acid mutation in the Homer binding domain (F1128R; mGlu5 ${ }^{R / R}$ ) (Cozzoli et al., 2009). We find that the mGlu $5^{R / R}$ mutation does not affect Homer interactions with other binding partners or FMRP levels but is sufficient to mimic multiple phenotypes of Fmr1 KO mice, including altered mGlu5 signaling, neurophysiology, and behavior. Our results reveal important roles for mGlu5-Homer scaffolds in brain function and behavior as well as implicate disrupted mGlu5-Homer in etiology of complex phenotypes associated with FXS.

\section{Materials and Methods}

Animals. Congenic mGlu5F1128R knock-in mice $\left(\mathrm{mGlu} 5^{R / R}\right)$ were generated as described previously (Cozzoli et al., 2009) and backcrossed at least 5 generations onto the C57BL/6J mice from the University of Texas Southwestern mouse breeding core facility. Congenic Fmr1 KO mice
(Dutch-Belgian Fragile X Consortium, 1994) were bred on the C57BL/6J background. All experiments were performed on littermate controls and blind to mouse genotype. Male and female mice were used. Mice were housed individually in an Association for Assessment and Accreditation of Laboratory Animal Care-approved animal facility in standard mouse cages (lights on at $0800 \mathrm{~h} ; 25 \mathrm{C}$ ). All testing was conducted during the light cycle. Unless otherwise indicated, food and water were available ad libitum. All experiments were approved by the Institutional Animal Care and Use Committee at University of Texas Southwestern, Baylor College of Medicine and University of California Santa Barbara and conducted in accordance with the National Institutes of Health Principles of Laboratory Animal Care.

Reagents. Drugs were prepared as stocks, stored at $-20^{\circ} \mathrm{C}$, and used within $10 \mathrm{~d}$. The mixed group I mGluR agonist (RS)-3,5-dihydroxyphenylglycine (DHPG) and the negative allosteric modulator (NAM) for mGlu5, 2-methyl-6-(phenylethynyl)pyridine hydrochloride (MPEP) were made as stocks in water. The mitogen-activated protein (MAP)/ ERK kinase (MEK) inhibitor U0126 was prepared as $1000 \times$ stock in DMSO. Appropriate vehicle controls were performed for each drug. All drugs were purchased from Tocris Bioscience.

Hippocampal slice preparation and LTD recordings. Acute hippocampal brain slices were prepared from 3- to 6-week-old wild-type (WT) and mGlu $5^{R / R}$ littermates as described previously (Jakkamsetti et al., 2013). Briefly, mice were anesthetized with ketamine $(125 \mathrm{mg} / \mathrm{kg}) /$ xylazine $(25$ $\mathrm{mg} / \mathrm{kg})$ and transcardially perfused with chilled $\left(4^{\circ} \mathrm{C}\right)$ sucrose dissection buffer containing the following (in $\mathrm{mm}$ ): $2.6 \mathrm{KCl}, 1.25 \mathrm{NaH}_{2} \mathrm{PO}_{4}, 26$ $\mathrm{NaHCO}_{3}, 0.5 \mathrm{CaCl}_{2}, 5 \mathrm{MgCl}_{2}, 212$ sucrose, and 10 dextrose aerated with $95 \% \mathrm{O}_{2} / 5 \% \mathrm{CO}_{2}$. Hippocampi were dissected, and transverse hippocampal slices were obtained on a Leica VT1000S slicer. CA3 was cut off to avoid epileptogenic activity induced by DHPG. Slices recovered at and were maintained at $30^{\circ} \mathrm{C}$ in ACSF. ACSF contained the following (in $\mathrm{mm}$ ): $119 \mathrm{NaCl}, 2.5 \mathrm{KCl}, 2 \mathrm{CaCl} 2,1 \mathrm{MgCl} 2,26 \mathrm{NaHCO} 3,1 \mathrm{NaH}_{2} \mathrm{PO}_{4}$ and 11 D-glucose aerated with $95 \% \mathrm{O}_{2} / 5 \% \mathrm{CO}_{2}$ to $\mathrm{pH}$ 7.4. Anisomycin was prepared fresh daily as a $10 \times$ stock in ACSF.

Western blotting. Western blotting was performed on forebrain homogenates or on hippocampal slices, where indicated, and as previously described (Ronesi et al., 2012). Hippocampal slices were lysed with lysis buffer (50 mm Tris, pH 7.4, $120 \mathrm{~mm} \mathrm{NaCl,} 50 \mathrm{~mm} \mathrm{NaF}$, and 1\% Triton X-100, containing Protease Inhibitor Mixture, Sigma; P8340; and phosphatase inhibitor mixture 2 and 3, Sigma; P5726 and P0040). Samples were homogenized using brief (1-2 s) pulses of sonication with an ultrasonic cell disruptor until lysates were clear. Lysates were then centrifuged at $15,700 \times g$ for $10 \mathrm{~min}$ at $4^{\circ} \mathrm{C}$, the pellets discarded, and protein levels in the supernatant were measured using Pierce BCA kit. After SDS-PAGE, proteins were transferred onto PVDF membranes. After blocking with $5 \%$ BSA in $1 \times$ TBS, $0.05 \%$ Tween 20 for $1 \mathrm{~h}$, membranes were incubated with the following primary antibodies in blocking buffer overnight at $4^{\circ} \mathrm{C}$ : P-T56 EF2, total-EF2, P-S2448 mTORC1, total mTORC1, P-T202/ Y204 ERK, total-ERK, P-S209-eIF4E, P-T37/46-4EBP, P-S65-4EBP total 4EBP, eIF4G, eIF4E (all from Cell Signaling Technology), Map1b (rabbit polyclonal; gift from Dr. Itzhak Fischer, Drexel University), and actin (Millipore, MAB1501). After three washes of $1 \times$ TBS, $0.05 \%$ Tween 20 , $10 \mathrm{~min}$ each, membranes were incubated with appropriate HRPconjugated secondary antibodies in 5\% milk in $1 \times$ TBS, $0.05 \%$ Tween 20 for $1 \mathrm{~h}$ at room temperature, then washed the membrane three times in $1 \times$ TBS, $0.05 \%$ Tween 20, 10 min each, and developed using the ECL. For comparison of phosphoprotein levels across conditions or genotypes, immunoreactive phosphoprotein bands were normalized to total protein levels from the same slice homogenates (e.g., P-mTORC1/ mTORC1), each of which was first normalized to loading control (either tubulin or actin where indicated).

Coimmunoprecipitation. Neocortex and hippocampi were lysed in coimmunoprecipitation buffer (50 mm Tris, pH 7.4, $120 \mathrm{~mm} \mathrm{NaCl,} \mathrm{1 \%}$ Triton X-100), and protein was tumbled overnight at $4^{\circ} \mathrm{C}$ with $1 \mu \mathrm{g}$ of antibody: either to Homer (Santa Cruz Biotechnology, D-3), or eIF4G (Cell Signaling Technology). Protein A/G agarose bead slurry (Thermo Scientific) was added for one additional hour, and the beads were then washed with coimmunoprecipitation buffer. Western blotting was performed with antibodies against Homer (Santa Cruz Biotechnology, E-18 
sc-8921), mGlu5 and PIKE-L (Millipore), mGlu1 $\alpha$ (BD Biosciences; \#556389), Shank3 (JH3025) (Kouser et al., 2013), eIF4E, and eIF4G (Cell Signaling Technology), or FMRP (2F5; gift from Dr. Jennifer Darnell, Rockefeller University) (Gabel et al., 2004).

Isolation of the postsynaptic density (PSD) fractions. The forebrain PSD fractions were prepared as previously described (Carlin et al., 1980; Villasana et al., 2006). All the solutions contained protease inhibitor mixture (Sigma), phosphatase inhibitor mixture 2 and 3 (Sigma). Isolated synaptoneurosomes were diluted with an equal volume of solution (1\% Triton $\mathrm{X}-100$ in $0.32 \mathrm{~m}$ sucrose, $12 \mathrm{~mm}$ Tris- $\mathrm{HCl}, \mathrm{pH}$ 8.1). The samples were stirred for $15 \mathrm{~min}$ at $4^{\circ} \mathrm{C}$ cold room and then centrifuged for $20 \mathrm{~min}$ at $\sim 30,000 \times g$. The pellet was resuspended with solution $(0.32 \mathrm{M}$ sucrose, $1 \mathrm{mM} \mathrm{NaHCO}_{3}$ ) and layered onto a sucrose gradient of $1.5 \mathrm{~m}$ sucrose, 1 $\mathrm{mM} \mathrm{NaHCO}_{3}$, and $1.0 \mathrm{M}$ sucrose, $1 \mathrm{~mm} \mathrm{NaHCO}$ and centrifuged at $\sim 167,000 \times g$ for $2 \mathrm{~h}$. The pellet was resuspended with solution $(0.32 \mathrm{M}$ sucrose, $1 \mathrm{~mm} \mathrm{NaHCO}$ ) and added to an equal amount of solution( $1 \%$ Triton X-100 $150 \mathrm{~mm} \mathrm{KCl} \mathrm{buffer)} \mathrm{and} \mathrm{centrifuged} \mathrm{at} 167,000 \times g$ for 30 min. The resulting pellet was resuspended in protein loading buffer for Western blot.

Immunocytochemistry. Dissociated cortical neuron cultures were prepared from postnatal $(\mathrm{P})$ day $0-1 \mathrm{WT}$ or $\mathrm{mGlu} 5^{R / R}$ littermates as described previously (Tsai et al., 2012). All experiments were performed on at least three independent cultures with two or three different coverslips per condition. Neurons at $14-18$ DIV were fixed in $4 \%$ PFA $\left(37^{\circ} \mathrm{C}, 15\right.$ min), permeabilized in $0.2 \%$ Triton $\mathrm{X}(10 \mathrm{~min})$, washed, and then incubated in primary anti-mGlu5 (1:500; Millipore), primary anti$\beta 3$-tubulin (1:600; Abcam). Primary antibodies were detected with subsequent application of the appropriate AlexaFluor-555-, or AlexaFluor-488-conjugated secondary antibody (Invitrogen). Fluorescence images were acquired on a Nikon TE2000 microscope with a cooled CCD camera (CoolSnap HQ; Roper Scientific) and quantified with MetaMorph Meta Imaging Series software (Molecular Devices) as described previously (Niere et al., 2012).

Metabolic labeling of hippocampal slices. Protein synthesis rates in acute hippocampal slices were performed as previously described (Osterweil et al., 2010; Ronesi et al., 2012). Briefly, slices were prepared for electrophysiology, except that the most ventral slices (2 per hippocampus) were used because basal protein synthesis rates differ between dorsal and ventral hippocampal slices (Osterweil et al., 2010). Slices recovered for $3.5 \mathrm{~h}$ in ACSF at $32^{\circ} \mathrm{C}$ and then were incubated in actinomycin D $(25 \mu \mathrm{M})$ for $30 \mathrm{~min}$. Slices were then incubated in actinomycin D and $10 \mu \mathrm{Ci} / \mathrm{ml}$ of ${ }^{35} \mathrm{~S}$ labeled Met/Cys (express protein labeling mix, PerkinElmer) for $1 \mathrm{~h}$. Where indicated, $20 \mu \mathrm{M}$ U0126 or $10 \mu \mathrm{M}$ MPEP was added at this step.

Neocortical slice preparation and UP state recordings. Spontaneous UP states were recorded from acute neocortical slices prepared from (P18P25) WT, HET, and mGlu5 $5^{R / R}$ littermates as described previously (Hays et al., 2011; Ronesi et al., 2012). Briefly, mice were anesthetized with Euthasol (containing sodium pentobarbital; $50 \mathrm{mg} / \mathrm{kg}$ ) and decapitated. The brain was transferred into ice-cold dissection buffer containing the following (in mM): $87 \mathrm{NaCl}, 3 \mathrm{KCl}, 1.25 \mathrm{NaH}_{2} \mathrm{PO}_{4}, 26 \mathrm{NaHCO}_{3}, 7 \mathrm{MgCl}_{2}$, $0.5 \mathrm{CaCl}_{2}, 20 \mathrm{D}$-glucose, 75 sucrose, and 1.3 ascorbic acid aerating with $95 \% \mathrm{O}_{2}-5 \% \mathrm{CO}_{2}$. Thalamocortical slices $(400 \mu \mathrm{m})$ were made on an angled block (Agmon and Connors, 1991) using a vibratome (Vibratome 1000 Plus). Following cutting, slices were transected parallel to the pia mater to remove the thalamus and midbrain. Slices were immediately transferred to an interface recording chamber (Harvard Instruments) and allowed to recover for $1 \mathrm{~h}$ in ACSF at $32^{\circ} \mathrm{C}$ containing the following (in mM): $126 \mathrm{NaCl}, 3 \mathrm{KCl}, 1.25 \mathrm{NaH}_{2} \mathrm{PO}_{4}, 26 \mathrm{NaHCO}_{3}, 2 \mathrm{MgCl}_{2}, 2 \mathrm{CaCl}_{2}$, and $25 \mathrm{D}$-glucose.

For UP state recordings, $45 \mathrm{~min}$ before the beginning of recording session, slices in the interface chamber were perfused with an ACSF, which mimics physiological ionic concentrations in vivo (Sanchez-Vives and McCormick, 2000; Gibson et al., 2008), containing the following (in mu): $126 \mathrm{NaCl}, 5 \mathrm{KCl}, 1.25 \mathrm{NaH}_{2} \mathrm{PO}_{4}, 26 \mathrm{NaHCO}_{3}, 1 \mathrm{MgCl}_{2}, 1 \mathrm{CaCl}_{2}$, and $25 \mathrm{D}$-glucose. Spontaneously generated UP states were recorded using $0.5 \mathrm{M} \Omega$ tungsten microelectrodes (FHC) placed in layer 4 of somatosensory cortex. Ten minutes of spontaneous activity was collected from each slice. Recordings were amplified $10,000 \times$ and filtered online between $500 \mathrm{~Hz}$ and $3 \mathrm{kHz}$. All measurements were analyzed off-line using custom Labview software. For visualization and analysis of UP states, traces were offset to zero, rectified, and low-pass filtered with a $0.2 \mathrm{~Hz}$ cutoff frequency. The threshold for detection was set at $4 \times$ the root mean square noise. An event was defined as an UP state when its amplitude remained above the threshold for at least $200 \mathrm{~ms}$. The end of the UP state was determined when the amplitude decreased below threshold for $>600$ $\mathrm{ms}$. Two events occurring within $600 \mathrm{~ms}$ of one another were grouped as a single UP state. UP state amplitude was defined based on the filtered/ rectified traces and was unitless because it was normalized to the detection threshold. This amplitude may be considered a coarse indicator of the underlying firing rates of neuronal populations.

Audiogenic seizures. Mice (21 to $23 \mathrm{~d}$ old) were placed in a plastic chamber $(30 \times 19 \times 12 \mathrm{~cm})$ containing a siren (GE 50246 personal security alarm) and covered with a Styrofoam lid. A 110-120 dB siren was presented to mice for $5 \mathrm{~min}$. Mice were videotaped and scored for behavioral phenotype: $0=$ no response; $1=$ wild running; $2=$ tonicclonic seizures; 3 = status epilepticus/death as described previously (Dölen et al., 2007; Ronesi et al., 2012).

Behavioral measurements. Open field activity experiments were performed as described previously (Thomas et al., 2011). We used the open field activity assay to evaluate activity and anxiety-related responses. The VersaMax Animal Activity Monitoring System (AccuScan Instruments), consisting of a clear Plexiglas $(40 \times 40 \times 30 \mathrm{~cm})$ open-field arena, recorded animal activity. Activity was recorded for $30 \mathrm{~min}$ in the presence of overhead bright lights ( $750 \mathrm{lux}$ ) and white noise ( $55 \mathrm{~dB})$. The following parameters were analyzed: total distance traveled $(\mathrm{cm})$ and center distance ratio (anxiety measure) defined as the ratio between the distance traveled in the center $(22.5 \mathrm{~cm} \times 22.5 \mathrm{~cm})$ versus the total distance traveled.

Elevated Plus Maze was performed as described previously (Lee et al., 2015). Animals were placed on the center intersection of a 4 arm radial plus maze with 2 white open arms and 2 black-walled arms $24 \mathrm{~cm}$ high. Each arm measured $123 \mathrm{~cm}$ long $\times 5 \mathrm{~cm}$ wide. Latency to first open-arm entry, number of open-arm entries, and total time spent in an open arm were monitored for the $5 \mathrm{~min}$ trial by a trained observer who was blind to mouse genotype. Differences in the amount of time spent in an open versus enclosed arm were also used to assess anxiety.

Prepulse inhibition was performed as previously described (Szumlinski et al., 2005). Six different trial types were presented: startle pulse (st110, $110 \mathrm{~dB} / 40$ milliseconds), low prepulse stimulus given alone (st74, $74 \mathrm{~dB} / 20 \mathrm{~ms}$ ), high prepulse stimulus given alone (st90, $90 \mathrm{~dB} / 20 \mathrm{~ms}$ ), st74 or st 90 given $100 \mathrm{~ms}$ before the onset of the startle pulse (pp74 and pp90, respectively), and no acoustic stimulus (i.e., only background noise was presented; st0). St100, st0, pp74, and pp90 trials were applied 10 times, st74 and st90 trials were applied five times, and all trials were given in random order. The average intertrial interval was $15 \mathrm{~s}(10-20 \mathrm{~s})$, and the background noise of each chamber was $70 \mathrm{~dB}$. The data for startle amplitude were averaged across stimulus trials and analyzed by a genotype $\times$ stimulus ANOVA with repeated measures on the stimulus factor (st0, st74, st90, st110, pp74, and pp90). The percentage inhibition of the $110 \mathrm{~dB}$ startle by the 74 and $90 \mathrm{~dB}$ prepulse intensities was calculated for each animal, and the data were analyzed using a genotype $X$ intensity ANOVA with repeated measures on the intensity factor (74 vs $90 \mathrm{~dB}$ ).

The Porsolt Swim Test was performed as previously described in Homer KO mice (Lominac et al., 2005; Szumlinski et al., 2005). For this test, WT, Het, and mGlu5 $5^{R / R}$ mice were placed into Plexiglas buckets $(23 \times 24 \times 22 \mathrm{~cm})$ and allowed to swim for a period of $15 \mathrm{~min}$. During this time, the behavior of the mice was scored in $30 \mathrm{~s}$ intervals using a checklist for swimming (front and/or back paws mobile with horizontal displacement of the animal's center of gravity), floating (both front and back paws immobile), and climbing (swimming with front paws making contact with the walls of the pool) and the latency to first exhibit floating was determined using a stopwatch. The next day, a recall test was conducted in which mice were reexposed to the pool for $5 \mathrm{~min}$ and behavior, as well as latency to float, was recorded in $30 \mathrm{~s}$ intervals in a manner similar to that for the initial session. The data for each behavioral scoring measure were expressed as a percentage of the total number of observations recorded (30 observations for Test $1 ; 10$ observations for Test 2). 
The data were analyzed independently for each session using a univariate ANOVA across the genotype factor.

Statistics. Data plotted in the figures represent the mean \pm SEM. Significant differences were determined using independent or paired $t$ tests between WT and mGlu5 $5^{R / R}$. For comparisons between WT and mGlu5 $5^{R / R}$ with or without drug, a two-way ANOVA and post hoc multiple comparisons were used as indicated in the figure legends. For comparisons between WT, Het, and $\mathrm{mGlu} 5^{R / R}$, for the UP states, a one-way ANOVA and post hoc multiple comparisons were used. Statistics on nominal data, such as seizure severity and incidence, a $\chi^{2}$ (Fisher's Exact test) was used. Group data are presented in the figures as mean \pm SEM.

\section{Results \\ mGlu5F1128R knock-in mice have a selective disruption of Group 1 mGluRs and Homer}

To determine whether a specific disruption in mGlu5-Homer is sufficient to mimic known phenotypes of Fmrl KO mice, we examined an mGlu5 knock-in mouse with a point mutation (F1128R) in the C-terminal, intracellular Homer-binding site $\left(\mathrm{mGlu}^{R / R}\right)$ (Tu et al., 1998; Cozzoli et al., 2009). We first confirmed that the mGlu $5^{R / R}$ mice had reduced Homer interactions with mGlu5 and determined whether Homer interactions with other known Homer binding proteins were affected. Normal levels of total mGlu5 were observed in cortical lysates of mGlu5 $5^{R / R}$ mice, but coimmunoprecipitation of Homer revealed a near complete loss of mGlu5 interactions with long Homers ( $6 \pm 1 \%$ of WT; $p=0.003$ ) compared with WT littermates (Cozzoli et al., 2009) (Fig. $1 A, B$ ). To determine the specificity of this disruption for mGlu5, Homer immunoprecipitates from $\mathrm{mGlu}^{R / R}$ and WT brains were blotted for other Homer binding proteins, including PIKE-L, Shank3, and mGlu1 $\alpha$. Homer interactions with PIKE-L and Shank 3 were similar to WT, but reduced interactions with mGlu $1 \alpha$ in mGlu $^{R / R}$ cortex were observed $(68 \pm 4 \%$ of WT, $n=$ $4 ; p=0.01$; Fig. $1 A, B)$. Because mGlu1 $\alpha$ heterodimerizes with mGlu5 (Beqollari and Kammermeier, 2010; Doumazane et al., 2011), the decrease in mGlul $\alpha$-Homer interaction is likely an indirect effect of the abolished association of mGlu5-Homer. Total levels of long Homers, Shank3, mGlu1 $\alpha$, mGlu5, and FMRP in mGlu5 $5^{R / R}$ cortex were normal (Fig. $1 C, D$ ).

\section{A reduced association of mGlu5 with the PSD is observed in mGlu5 $5^{R / R}$ forebrain similar to Fmr1 KO}

Homer is present in the PSD where it interacts with other PSD scaffolding proteins, such as Shank (Tu et al., 1999; ShiraishiYamaguchi and Furuichi, 2007). Homer is known to regulate clustering of mGlu5 in dendrites (Ango et al., 2000), but it is unknown whether Homer interactions regulate association of mGlu5 with the PSD. In Fmr1 KO cortex, total mGlu5 levels are normal, but there are reduced levels of mGlu5 in a Triton $\mathrm{X}$-insoluble fraction that contains the PSD (Giuffrida et al., 2005), which may be a consequence of reduced Homer binding. Similar to what is observed in Fmr1 KO, mGlu5 levels in PSD fractions of $\mathrm{mGlu} 5^{R / R}$ forebrain were reduced, but total and synaptoneurosome levels of mGlu5 were normal (Fig. 1C-F). Long Homers and H1a may regulate surface expression and dendritic localization of mGlu5 (Ango et al., 2000), although different results have been obtained with exogenous (Roche et al., 1999; Ango et al., 2002) versus endogenous expression of Hla (Hu et al., 2010). Therefore, we examined dendritic expression of mGlu5 using immunocytochemistry of dissociated hippocampal neurons from WT, heterozygous (mGlu5 ${ }^{F / R} ;$ Het), and mGlu5 $5^{R / R}$ mice and found normal levels of dendritic mGlu5 on Het and mGlu $5^{R / R}$ dendrites (as normalized to $\beta$-tubulin; Fig. $1 G$ ). We also examined surface expression of mGlu5 using biotinylation of acute hippocampal brain slices prepared from WT, Het, and $\mathrm{mGlu} 5^{R / R}$ mice and found surface expression of $\mathrm{mGlu} 5^{R / R}$ to be normal (Fig. $1 H$ ). Our results illustrate the importance of Homer interactions for association of endogenous mGlu5 with the PSD and suggest that the reduced interactions of mGlu5 with Homer in the Fmr1 KO underlie the reduced PSD association of mGlu5.

\section{Selective disruption of mGlu5-Homer results in constitutive mGlu5-driven protein synthesis rates, translation initiation, and ERK signaling}

Enhanced protein synthesis rates are observed in Fmrl KO hippocampal slices and are reversed by pharmacological blockade of mGlu5 or extracellular-signal regulated kinase (ERK) (Gross et al., 2010; Osterweil et al., 2010; Ronesi et al., 2012). Another consequence of disrupted mGlu5-Homer interactions is constitutive, or agonist-independent mGlu5 activity (Ango et al., 2001), which may drive translation rates through ERK activation (Ronesi and Huber, 2008; Osterweil et al., 2010; Ronesi et al., 2012). To test this idea, we determined whether hippocampal slices of $\mathrm{mGlu}^{R / R}$ mice display enhanced mGlu5 and ERKdependent translation rates as observed in Fmr1 KO. Incorporation of ${ }^{35} \mathrm{~S}$ Met/Cys into protein was measured in acute hippocampal slices from WT and mGlu5 ${ }^{R / R}$ mice under basal conditions as described previously (Osterweil et al., 2010; Ronesi et al., 2012). Similar to what is observed in Fmrl KO mice, basal protein synthesis rates are elevated in mGlu $5^{R / R}$ slices (135 \pm $10 \%$ of WT; $p<0.005)$ and normalized by an mGlu5 NAM (MPEP; $10 \mu \mathrm{M}$; Fig. $2 A$ ) or an inhibitor of the upstream activating kinase of ERK (MEK) with U0126 (10 $\mu \mathrm{M})$ (Fig. 2B).

The enhanced translation rates in Fmrl KO brain may be due, in part, to enhanced translation initiation because of the observed increase in translation initiation complexes (Sharma et al., 2010; Ronesi et al., 2012). The eukaryotic initiation factor (eIF) 4F translation initiation complex is composed of the $5^{\prime}$ cap binding protein eIF4E, a scaffolding protein eIF4G, and the RNA helicase eIF4A (Proud, 2007) and is stimulated by Group 1 mGluR activation in WT animals (Sharma et al., 2010; Ronesi et al., 2012). To determine whether Homer binding to mGlu5 and constitutive mGlu5 activity stimulate translation initiation, we measured association of eIF4G and eIF4E using a coimmunoprecipitation. mGlu $5^{R / R}$ slices displayed enhanced eIF4E/4G interaction, which was reduced to WT levels by MPEP pretreatment. MPEP had no effect on eIF4E/4G interaction in WT slices (Fig. 2C,D). Together, these results indicate that disruption of mGlu5-Homer results in constitutive mGlu5 activity that drives translation initiation complex formation and increased translation rates through the ERK pathway.

Downstream effectors of ERK that regulate translation initiation are the cap-binding protein eIF4E and eIF4E binding protein (4EBP). ERK phosphorylates and activates MAPK-interacting kinase (Mnk), which in turn, phosphorylates eIF4E at S209 (Proud, 2007). ERK directly phosphorylates $4 \mathrm{EBP}$ at $\mathrm{S65}$, a distinct site from mTORC1-regulated sites (T37/46) (Herbert et al., 2002). The ERK-dependent phosphorylation of eIF4E and 4EBP (S65) is associated with increased translation rates in neurons (Kelleher et al., 2004; Banko et al., 2006; Gkogkas et al., 2014). Fmr1 KO mice hippocampi display enhanced phosphorylation of eIF4E and 4EBP at the ERK site (S65) that is reduced by MPEP treatment (Ronesi et al., 2012; Gkogkas et al., 2014). To determine whether constitutive mGlu5 activity in mGlu $5^{R / R}$ mice is sufficient to drive activation of ERK and downstream translation factors, we blotted lysates of acute hippocampal slices from WT and mGlu $5^{R / R}$ mice, treated with vehicle or MPEP $(10 \mu \mathrm{M} ; 45 \mathrm{~min})$ 
A

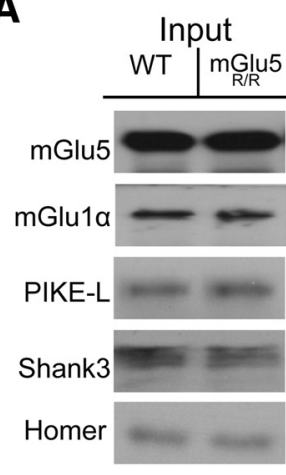

IP: Homer

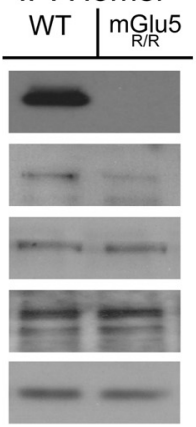

C

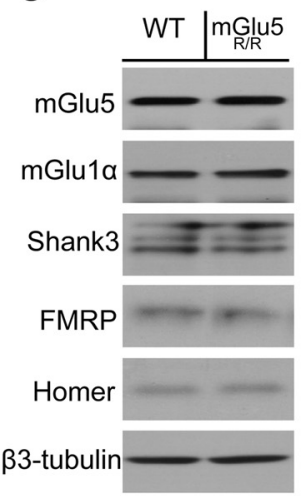

D

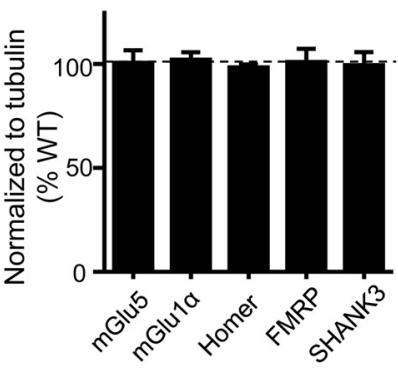

B

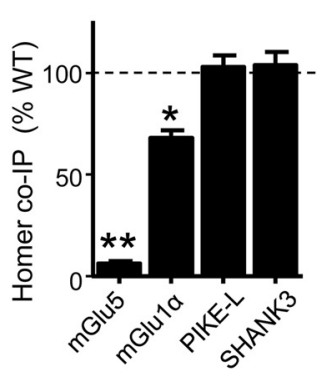

E

Total

$\underline{\mathrm{SN}}$

PSD

WT Het R/R WT Het R/R WT Het R/R

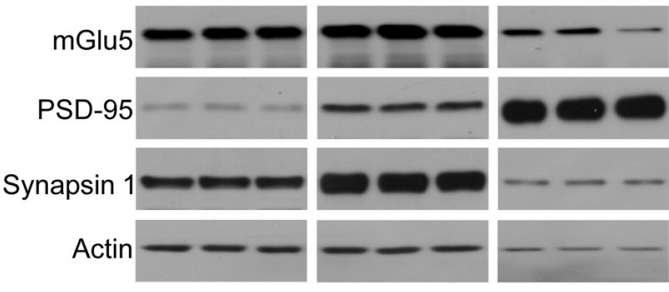

G

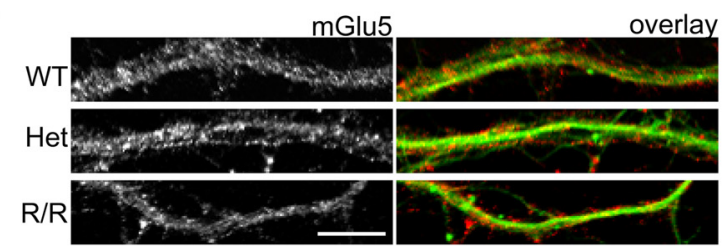

B3-tubulin
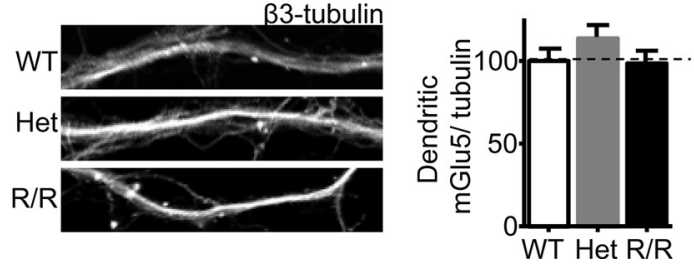

$\mathbf{F}$

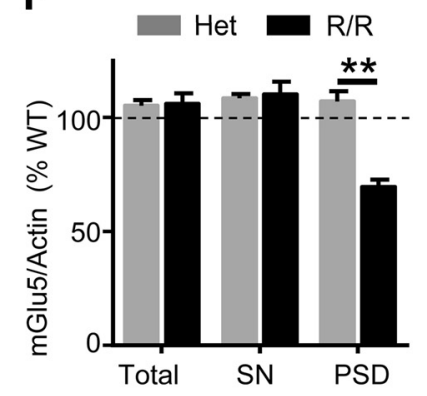

H

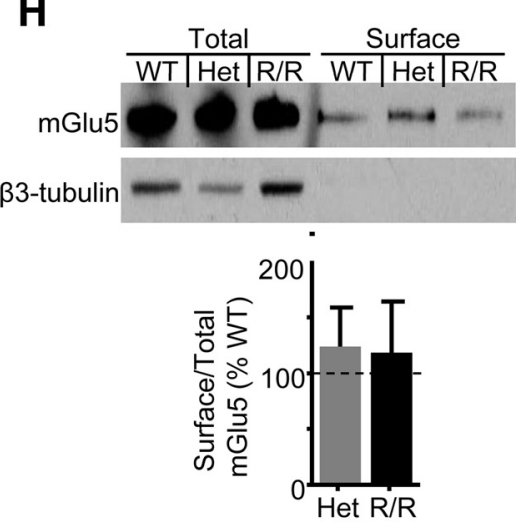

Figure 1. Selective disruption of mGlu5-Homer reduces PSD association, but not dendritic or surface expression of mGlu5. $\boldsymbol{A}$, Representative Western blots from coimmunoprecipitations using a pan long-Homer antibody of cortical homogenates of WT and mGlu5 $5^{R / R}$ littermates. $\boldsymbol{B}$, Quantified group data of the levels of mGlu5, mGlu1 $\alpha$, PIKE-L, and Shank3 that coimmunoprecipitate with Homer from mGlu5 ${ }^{R / R}$ cortical homogenates. Values are expressed as percentage (mean \pm SEM) of WT littermates $(n=3-5$ mice/genotype; one-sample $t$ test with Bonferroni correction for multiple comparisons). $\boldsymbol{C}, \boldsymbol{D}$, Representative Western blots and quantified group data demonstrating that total levels of mGlu5, mGlu1 $\alpha$, Shank3, FMRP, and long-Homers are normal in cortical homogenates of $\mathrm{mGlu} 5^{R / R}$ mice. Values are normalized to $\beta 3$-tubulin $(n=4-6$ mice/genotype). $\boldsymbol{E}, \boldsymbol{F}$, Representative Western blots and quantified group data of mGlu5 levels in total, synaptoneurosome $(S N)$ and PSD fractions of $\mathrm{mGlu} 5^{F / R}$ (Het) or mGlu $5^{R / R}$ littermate forebrains. Data are expressed as a percentage of WT levels. mGlu5 levels are normal in total and SN fractions but reduced in the PSD fractions of $\mathrm{mGlu} 5^{R / R}(n=3$ mice/genotype; two-way ANOVA, Sidak's post hoc). G, Representative immunofluorescence images of $\mathrm{mGlu} 5$ and $\beta 3$-tubulin in dendrites of dissociated cortical neuron cultures from WT, Het, or mGlu $5^{R / R}$ mice. Quantified group data reveal no effect of the $\mathrm{F}>$ R mutation on dendritic mGlu5 levels ( $n=45$ dendrites [ $15-30$ cells] $/$ genotype from 2 independent cultures). $\boldsymbol{H}$, Representative blots and quantified group data of total and surface (biotinylated) $\mathrm{mGlu}$ and $\beta 3$ tubulin in acute hippocampal slices prepared from WT, Het, or mGlu $5^{R / R}$ mice $\left(n=4\right.$ mice/genotype). ${ }^{*} p<0.05 .{ }^{* *} p<0.01$. 
using phosphospecific antibodies. We observed enhanced phosphorylation $(\mathrm{P})$ of 4EBP (S65), Mnk1 (Thr197/202), and its substrate eIF4E (S209; expressed as a ratio of total protein levels) in mGlu $5^{R / R}$ hippocampal slices that were reduced to WT levels by MPEP (Fig. 2E,F). Phosphorylated (P) 4EBP and P-eIF4E were elevated in fresh hippocampal homogenates from mGlu5 $5^{R / R}$ mice, indicating that these changes occur in vivo (Fig. 2G). Basal phosphorylation of ERK1/2 (Thr202/ Tyr204) was unchanged in $\mathrm{mGlu}^{R / R}$ slices and unaffected by MPEP (Fig. $2 E, F$ ) as previously observed in Fmrl KO hippocampal slices (Ronesi and Huber, 2008; Osterweil et al., 2010; Ronesi et al., 2012; but see Hou et al., 2006; Michalon et al., 2012). The results indicate that a dissociation of mGlu5-Homer is sufficient to drive ERK phosphorylation of translation initiation factors and enhance protein synthesis rates. It is unclear why we are able to detect elevated phosphorylation of ERK downstream substrates (P-Mnk1, P-eIF4e, P-4EBP (S65)) but not elevated P-ERK in Fmrl KO or mGlu5 $5^{R / R}$ slices. This result suggests that Homer regulates ERK accessibility to its substrates, as opposed to ERK activity per se. Homer regulates ERK interactions with mGlu5 through another Homer binding protein Presol (Hu et al., 2012) and may also function to scaffold to downstream ERK effectors.

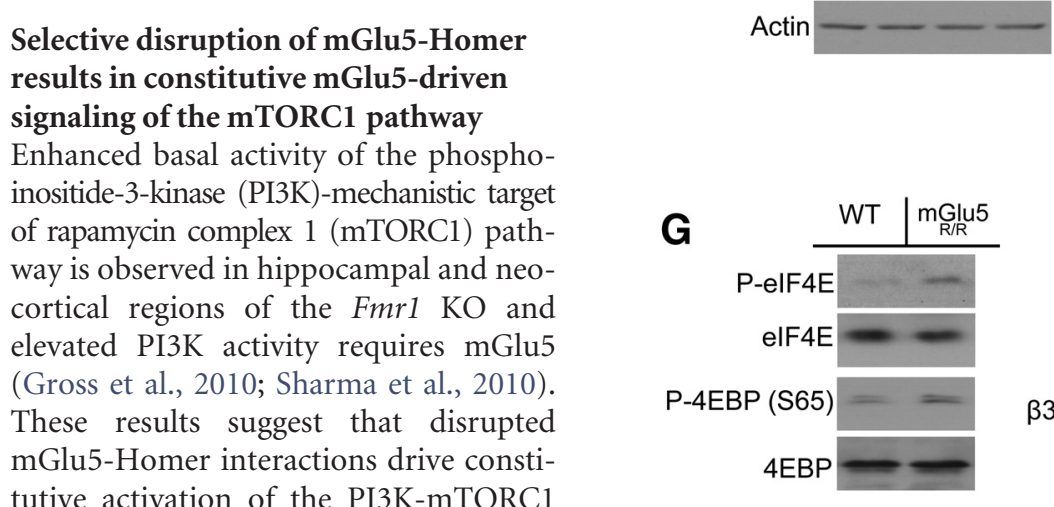

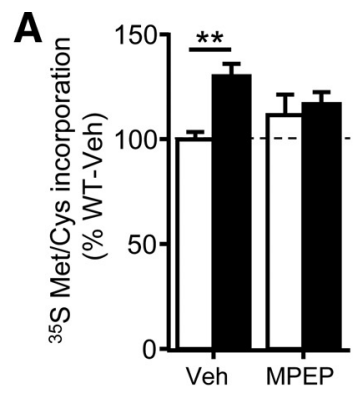
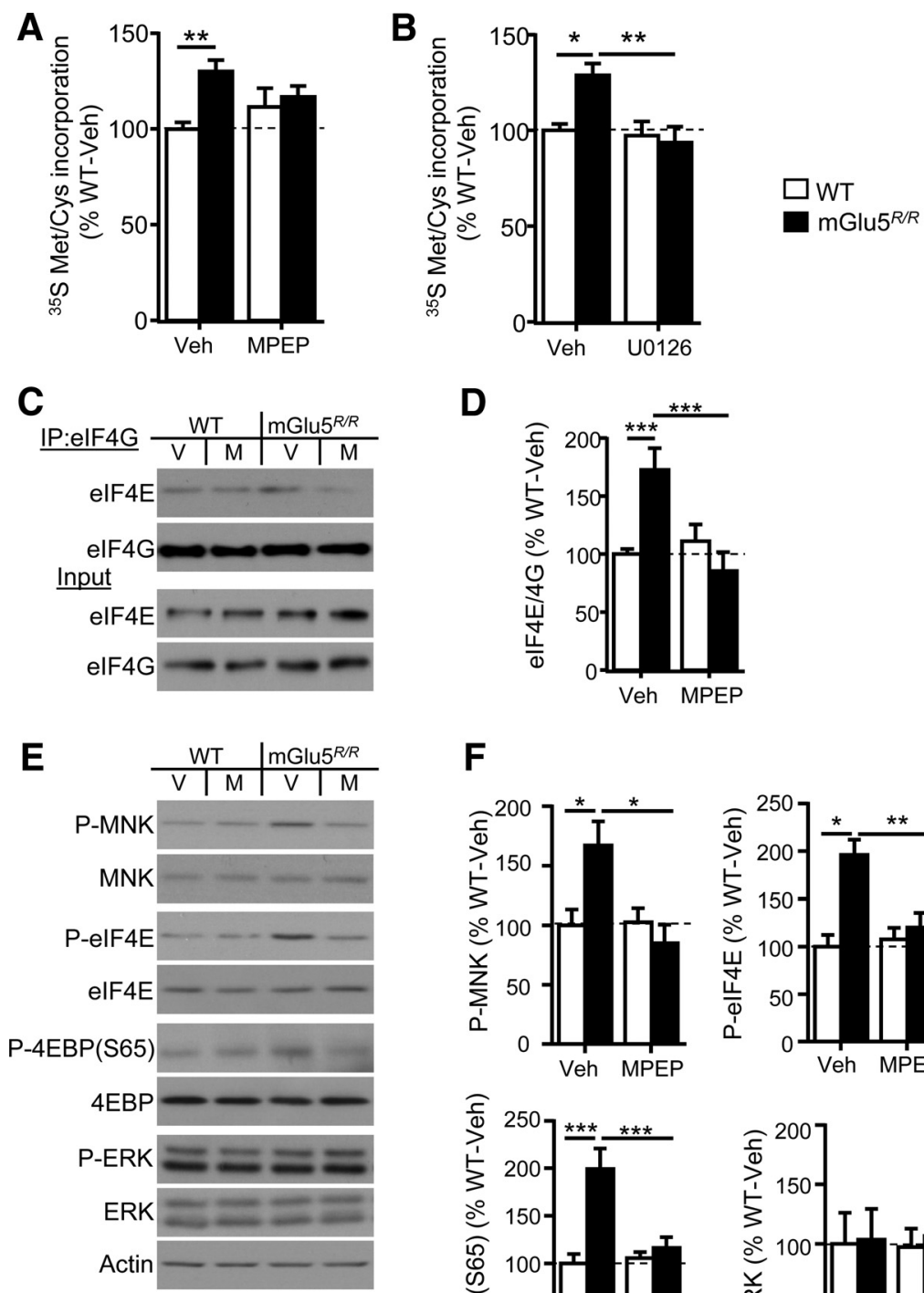

F
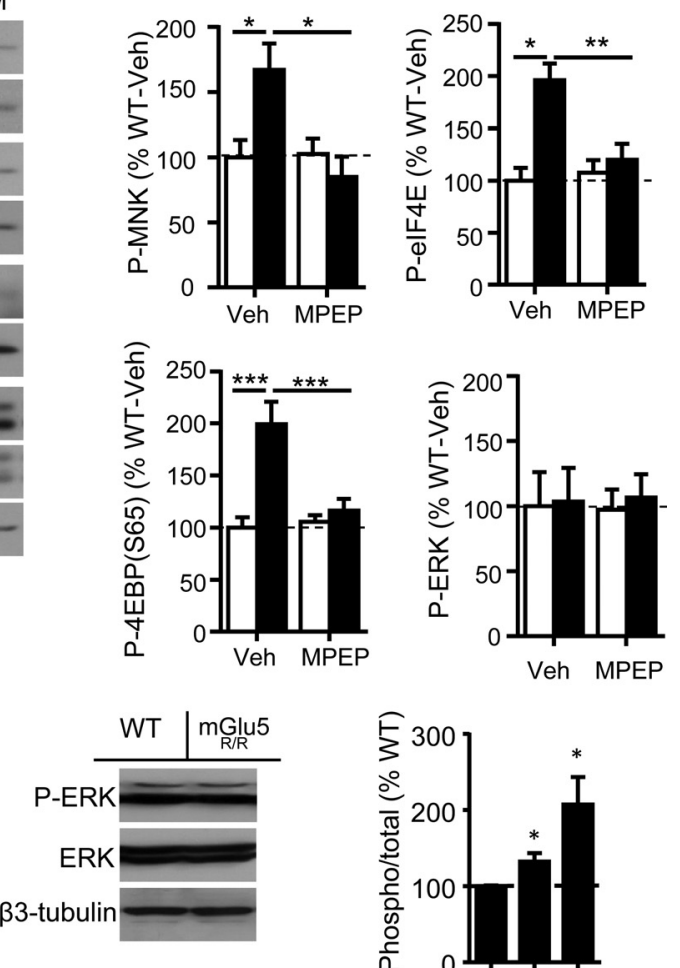
pathway (Rong et al., 2003; Banko et al., 2006; Ronesi and Huber, 2008). To test this idea, we measured phosphorylation of mTORC1 and its downstream substrates, 4EBP (T36/45) (Herbert et al., 2002) and p70 ribosomal S6 kinase (P$\mathrm{S} 6 \mathrm{~K}$ ) in hippocampal slices from WT and mGlu $5^{R / R}$ mice and the effects of MPEP. Slices from mGlu5 ${ }^{R / R}$ mice displayed enhanced levels of P-4EBP1 (T37/46) and P-S6K (T389), as a ratio of total levels, that was reduced to WT levels by MPEP pretreatment (Fig. 3A,B). MPEP also reduced levels of P-mTORC1 (S2448).

Figure 2. Selective disruption of mGlu5-Homer leads to constitutive mGlu5-driven signaling to ERK, translation initiation factors, and protein synthesis rates. $A$, Acute hippocampal slices from $\mathrm{mGlu} 5^{R / R}$ mice display elevated protein synthesis rates compared with WT littermates as measured by incorporation of ${ }^{35} \mathrm{~S}$ Met/Cys into total protein. Pretreatment with MPEP $(10 \mu \mathrm{M})$, an mGlu5 NAM, equalizes protein synthesis rates between WT and $\mathrm{mGlu} 5^{R / R}$ slices ( $n=14$ slices/condition from 7 mice/genotype). $\boldsymbol{B}$, In a separate set of experiments, inhibition of the MEK with U0126 $(10 \mu \mathrm{m})$ rescues protein synthesis rates in mGlu ${ }^{R / R}$ slices to WT levels ( $n=6$ slices/condition from 3 mice/genotype). C, $\boldsymbol{D}$, Representative Western blots and quantified group data reveal enhanced level translation initiation complexes in $\mathrm{mGlu}^{R / R}$ hippocampal slices, as measured by coimmunoprecipitation of elF4E with elF4G that are rescued by pretreatment with MPEP ( $n=4$ mice/genotype). $\boldsymbol{E}$, $\boldsymbol{F}$, Representative Western blots and quantified group data demonstrate elevated phosphorylation of translation initiation factors downstream of ERK (Mnk1; 4EBP, S65; elF4E) in acute hippocampal slices of $\mathrm{mGlu} 5^{R / R}$ mice that are rescued by pretreatment with MPEP. P-ERK levels are unchanged in $\mathrm{mGlu} 5^{R / R}$ slices and unaffected by MPEP ( $n=4$ mice/genotype). $G$, Western blots of fresh hippocampal lysates from WT and mGlu5 $5^{R / R}$ littermates demonstrate elevated P-4EBP (S65) and P-elF4E, but not P-ERK in vivo ( $n=5-7$ mice per genotype; one-sample $t$ test). $\boldsymbol{A}-\boldsymbol{F}$, Two-way ANOVA; Sidak's post hoc tests. ${ }^{*} p<0.05 .{ }^{* *} p<0.01 .{ }^{* * *} p<0.001$. 
A

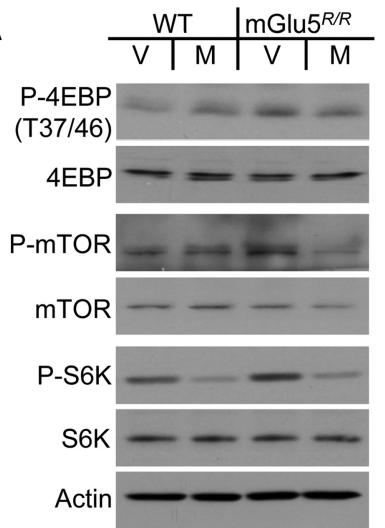

$\mathbf{B}$

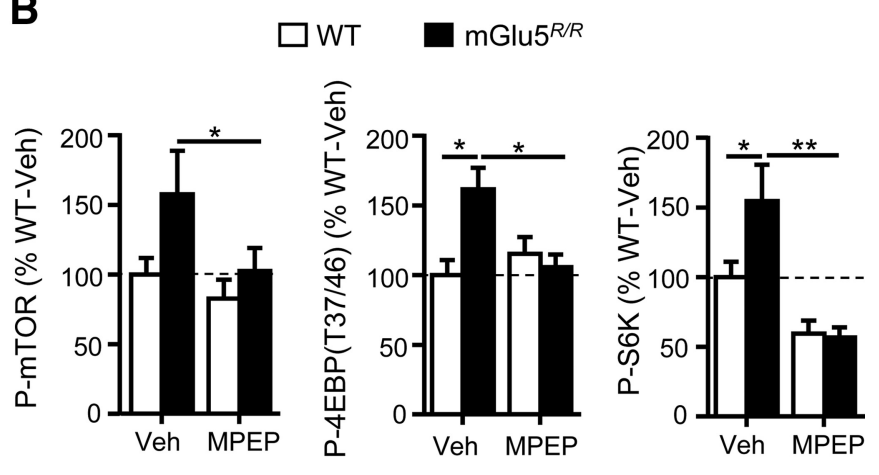

Figure 3. Selective disruption of mGlu5-Homer leads to constitutive mGlu5-driven signaling of the mTORC1 pathway. $A, B$, Representative Western blots and quantified group data demonstrate elevated mGlu5-dependent activity of the mTORC1 signaling pathway to translation factors in lysates of acute hippocampal slices of mGlu $5^{R / R}$ mice as measured by phosphorylation of mTORC1, 4 EBP (T37/46), and S6K. Pretreatment with MPEP reduces P-mTORC1, P-4EBP(T37/46), and P-S6K in mGlu5 ${ }^{R / R}$ slices to WT levels $n=4$ mice/genotype; mTORC1; paired $t$ test; 4EBP and S6K; two-way ANOVA; Sidak's post hoc tests). ${ }^{*} p<0.05 .{ }^{* *} p<0.01$.

Although MPEP had no effect on P-4EBP1 (T37/46) and $\mathrm{P}-\mathrm{mTORC1}$ in WT slices, it reduced P-S6K.

The enhanced mGlu5 driven activation of the ERK and mTORC1 pathways could be due to excess extracellular glutamate concentration in $\mathrm{mGlu} 5^{R / R}$ slices. If so, then other glutamatergic receptor pathways that regulate ERK and mTORC1, such as NMDA receptors (NMDAR) (English and Sweatt, 1996; RaabGraham et al., 2006), may also be basally activated in mGlu5 $5^{R / R}$ mice. To determine whether NMDAR activity contributes to the enhanced ERK and mTORC1 signaling pathways, we pretreated acute hippocampal slices from WT and $\mathrm{mGlu} 5^{R / R}$ mice with the NMDAR antagonist (RS)-3-(2-carboxypiperazin-4-yl)-propyl1-phosphonic acid (CPP; $5 \mu \mathrm{M} ; 45 \mathrm{~min})$. CPP had no effect on levels of P-eIF4E (vehicle $=144 \pm 20 \%$ of WT P-eIF4E levels; $\mathrm{CPP}=141 \pm 20 \% ; p=0.9)$ or P-mTORC1 in mGlu $5^{R / R}$ slices (vehicle $=153 \pm 17 \%$ of WT P-mTORC1 levels; $\mathrm{CPP}=156 \pm$ $24 \% ; n=4$ mice; $p=0.9)$. Similarly, CPP did not affect levels of P-eIF4E $(\mathrm{CPP}=96 \pm 17 \%$ of WT vehicle; $p=0.9)$ or P-mTORC1 (CPP $=108 \pm 15 \%$ of WT vehicle; $n=4$ mice; $p=$ 0.75 ) in WT slices (data not shown). These results suggest that the enhanced ERK and mTORC1 activity in $\mathrm{mGlu} 5^{R / R}$ mice is driven by constitutively active mGlu5.

\section{mGlu5-Homer is necessary for agonist-induced signaling to translation initiation and translation of plasticity-related proteins}

In WT neurons, the mGlu1/5 agonist, DHPG, induces activation of PI3K-mTORC1 and ERK-regulated translational control pathways, formation of the eIF4F initiation complex, and rapid synthesis of new proteins, such as Map1b (microtubuleassociated protein 1B) (Davidkova and Carroll, 2007) and APP (amyloid precursor protein) (Westmark and Malter, 2007). In Fmr1 KO neurons, Group1 mGluR agonist-induced activation of these translational control pathways and synthesis of new proteins are deficient (Hou et al., 2006; Westmark and Malter, 2007; Ronesi and Huber, 2008; Osterweil et al., 2010; Sharma et al., 2010; Ronesi et al., 2012), although DHPG-induced activation of ERK is normal (Ronesi and Huber, 2008; Osterweil et al., 2010; Ronesi et al., 2012; but see Hou et al., 2006).

We hypothesized that alterations in agonist-induced signaling to translational control in the Fmr1 KO are a result of dissociation of mGlu5 from Homer and would be mimicked in the mGlu5 $5^{R / R}$ mice. To test this hypothesis, we treated acute hippocampal brain slices from WT and $\mathrm{mGlu} 5^{R / R}$ mice with the Group $1 \mathrm{mGluR}$ agonist, DHPG (100 $\mu \mathrm{M} ; 5 \mathrm{~min})$ and measured activation of translational control pathways using Western blots with phosphorylation site-specific antibodies. Consistent with our previous experiments (Fig. 2), basal levels of P-mTORC1 (S2448) and $\mathrm{P}$-(T37/46) 4EBP1 were elevated in $\mathrm{mGlu} 5^{R / R}$ slices compared with WT. DHPG treatment of WT slices enhanced P-mTORC1 and P-4EBP1 (T37/46) but failed to increase their levels in mGlu5 $5^{R / R}$ slices (Fig. $4 A, B$ ). Although basal and DHPG-induced P-ERK was normal in mGlu $5^{R / R}$ slices (Fig. 4C,D), DHPGinduced phosphorylation of downstream ERK substrates, P-(S65) 4EBP, P-Mnk1, and the Mnk1 substrate, P-eIF4E, were deficient. We observed in this experiment, as in Figure 2, elevated basal levels of P-(S65) 4EBP, P-Mnk1, and P-eIF4E, but not $\mathrm{P}-\mathrm{ERK}$, in $\mathrm{mGlu} 5^{R / R}$ slice lysates (Fig. $4 C, D$ ). Because DHPGinduced P-4EBP and P-eIF4E was deficient in $\mathrm{mGlu} 5^{R / R}$ slices, we predicted a deficit in DHPG-induced stimulation of the eIF4F translation initiation complex. In support of this prediction, DHPG treatment of WT slices stimulated association of eIF4E/ eIF4G, as measured using coimmunoprecipitations, whereas in mGlu $5^{R / R}$ slices, $4 \mathrm{E} / 4 \mathrm{G}$ levels were elevated basally and DHPG failed to further increase this association (Fig. $4 E, F$ ). The elevated basal activation of ERK and MTORC1 pathways and translation initiation in $\mathrm{mGlu} 5^{R / R}$ slices may occlude or prevent subsequent DHPG-induced activation. Alternatively, or in addition, intact Homer scaffolds may be necessary for agonistinduced stimulation of these pathways (Rong et al., 2003).

Group1 mGluRs may also regulate translation elongation through activation of eukaryotic elongation factor 2 kinase (EF2K) and phosphorylation of elongation factor 2 (EF2) (Park et al., 2008). Although phosphorylation of EF2 generally inhibits translation elongation, it promotes translation of specific mRNAs, such as Arc (activity-regulated cytoskeleton associated protein), $\alpha$ CaMKII, and Map1b (Davidkova and Carroll, 2007; Park et al., 2008; Heise et al., 2014). EF2K interacts with Homer, as well as directly with mGlu5 (Park et al., 2008). If or how Homer regulates $\mathrm{mGlu} 5$ activation of $\mathrm{EF} 2 \mathrm{~K}$ is unknown. DHPG-induced P-EF2 is enhanced in Fmr1 KO mice and restored to WT levels by deletion of $\mathrm{Hla}$ (Ronesi et al., 2012), suggesting that disruption of mGlu5-Homer promotes mGlu5 activation of EF2K. In support of this idea, DHPG-induced phosphorylation of EF2 (T56) was greatly enhanced in mGlu $5^{R / R}$ slices (Fig. $4 G$ ). However, basal levels of P-EF2 in $\mathrm{mGlu} 5^{R / R}$ slices tended to be reduced. The 
A

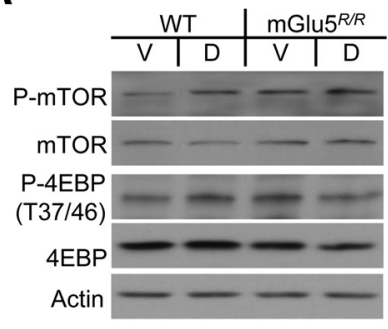

C
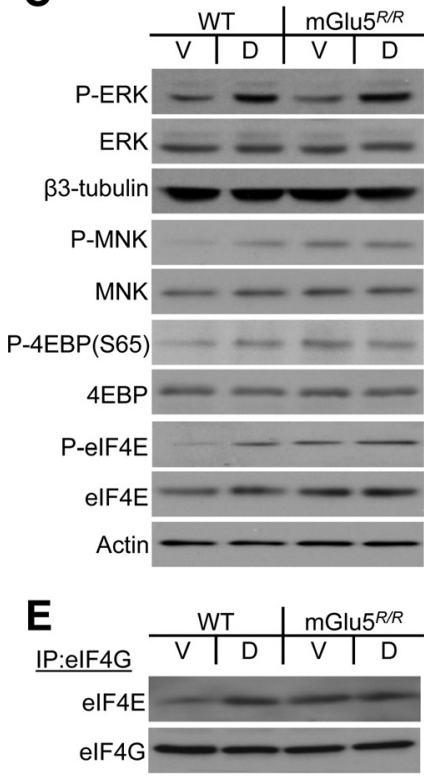

Input

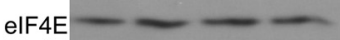

elF4G ---

H

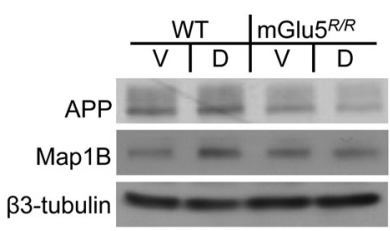

B
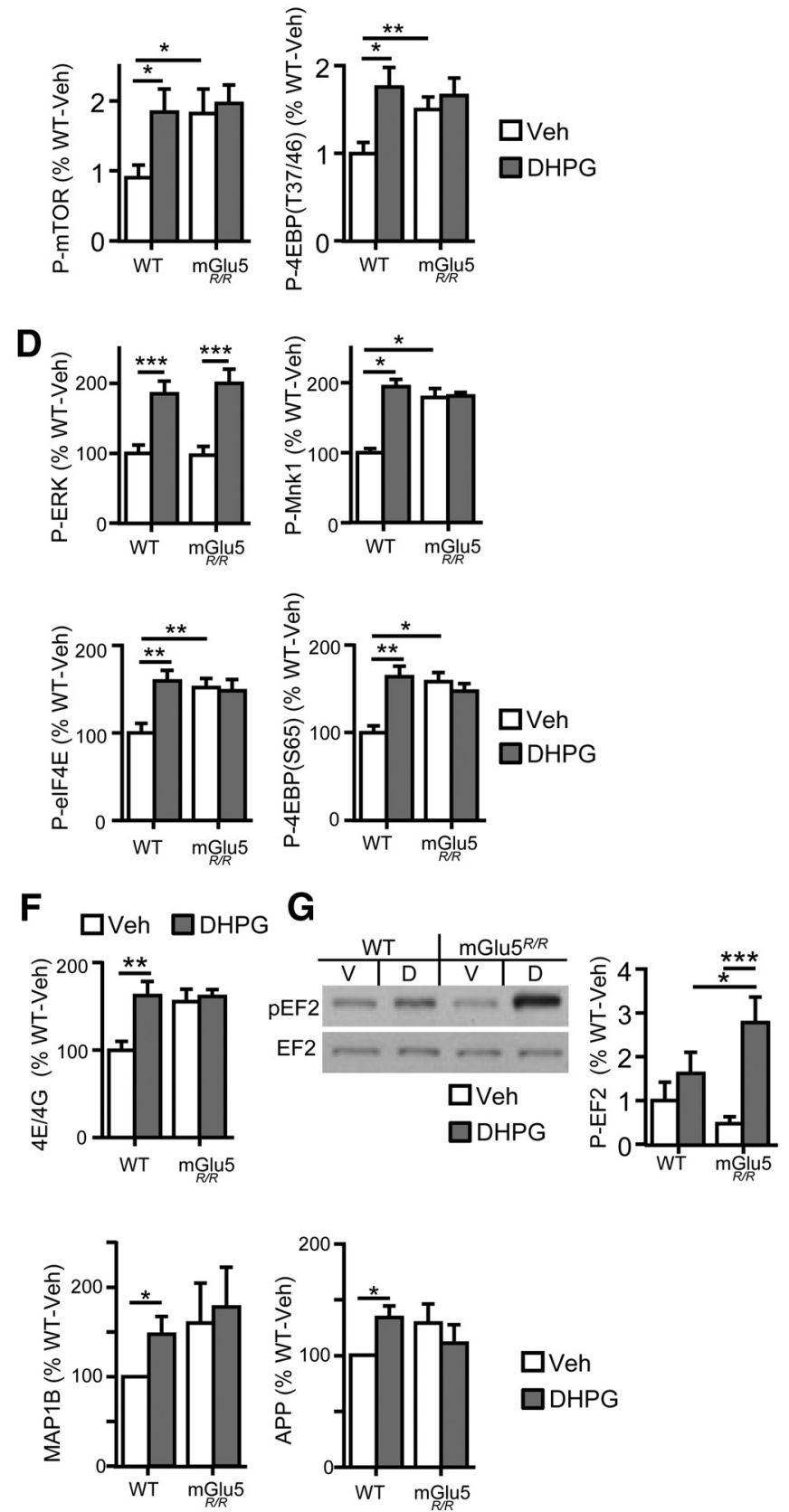

Figure 4. Selective disruption of mGlu5-Homer alters agonist-induced signaling to translation initiation and elongation. $\boldsymbol{A}, \boldsymbol{B}$, Representative Western blots and quantitative group data demonstrate enhanced basal activity of the mTORC1 pathway in acute hippocampal slices from mGlu5 $5^{R / R}$ compared with WT mice, as measured by P-mTORC1 and P-4EBP (T37/46). Treatment with the Group1 mGluR agonist, DHPG (D; $100 \mu \mathrm{m} ; 5 \mathrm{~min}$ ) increases P-mTORC1 and P-4EBP levels in WT slices, but not mGlu5 ${ }^{R / R}$ slices ( $n=4-6$ mice/genotype). C, D, Enhanced basal activity of translation factors downstream of ERK is observed using Western blots of acute hippocampal slice lysates from mGlu $5^{R / R}$ compared with WT mice, as measured by P-Mnk1, $\mathrm{P}$-elF4E, and P-4EBP (S65). Although DHPG treatment (100 $\mu \mathrm{m} ; 5 \mathrm{~min})$ increases P-ERK in mGlu5 ${ }^{R / R}$ slices, it fails to increase P-Mnk1, P-elF4E, and P-4EBP (S65) levels $(n=4-10$ mice/genotype). E, $\boldsymbol{F}$, Enhanced levels of elF4E coimmunoprecipitation with elF4G (elF4E/4G) from lysates of acute hippocampal slices of $\mathrm{mGlu} 5^{R / R}$ mice, compared with WT mice. Treatment with DHPG increases $4 \mathrm{E} / 4 \mathrm{G}$ levels in WT slices, but not in $\mathrm{mGlu}^{R / R}$ slices ( $n=6$ mice/genotype). G, DHPG treatment of acute hippocampal slices from mGlus $5^{R / R}$ mice results in greater P-EF2, compared with slices from WT mice ( $n=15$ mice/genotype). $\boldsymbol{H}$, DHPG treatment results in rapid increases in MAP1b and APP levels in acute hippocampal slices from WT, but not mGlu $5^{R / R}$ mice $(n=9-14$ mice/genotype). $\boldsymbol{A}-\boldsymbol{H}$, Two-way ANOVA; Sidak's post hoc tests. ${ }^{*} p<0.05 .{ }^{* *} p<0.01 .{ }^{* * *} p<0.001$.

robust phosphorylation of EF2 in response to DHPG would be expected to strongly inhibit translation elongation. This effect, combined with deficient activation of translation initiation (see Fig. 8), would be expected to inhibit the overall ability of Group1 mGluR agonists to activate translation.

To determine whether disruption of mGlu5-Homer interactions is sufficient to block Group1 mGluR-induced translation of specific proteins, we measured DHPG-induced increases in APP and Map1B, FMRP target mRNAs, which are translated in response to Group1 mGluRs (Davidkova and Carroll, 2007; Westmark and Malter, 2007; Darnell et al., 2011). In acute hippocampal slices from WT mice, DHPG increased the expression of both APP and MAP1b (APP; $134 \pm 10 \%$ of basal; MAP1b; $147 \pm 20 \% ; n=9-14$ slices/condition from $7-9$ mice). In 

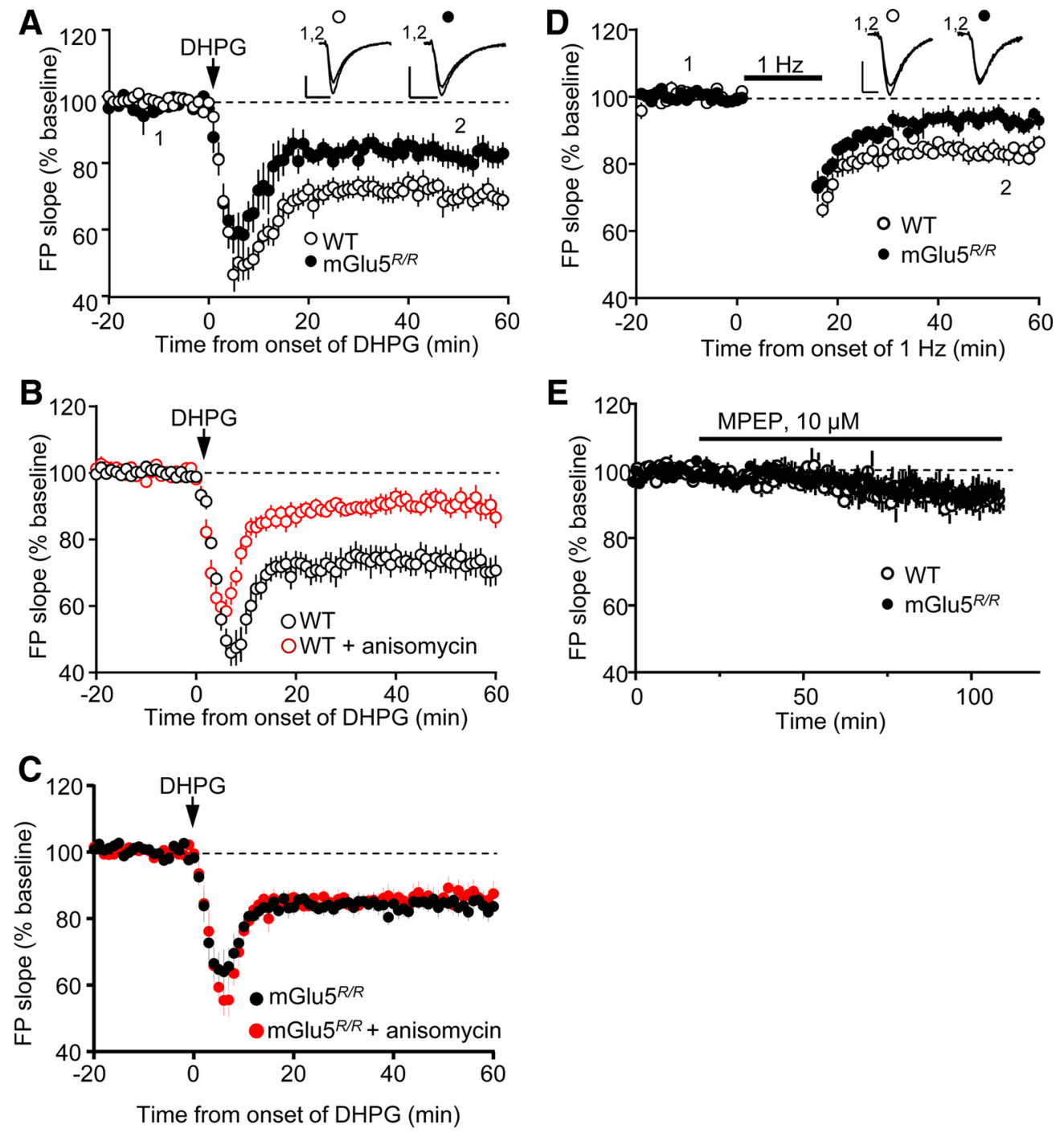

Figure 5. Disruption of mGlu5-Homer prevents mGlu1/5 agonist-induced, translation-dependent LTD. $A$, Brief DHPG (100 $\mu \mathrm{m} ; 5 \mathrm{~min})$ induces LTD of synaptic transmission in WT hippocampal slices $(n=14)$ that is reduced in slices of $\mathrm{mGlu} 5^{R / R}$ mice $(n=11 ; p<0.05 ; t$ test). Plotted are group averages of fEPSP slope (mean \pm SEM) normalized to pre-DHPG baseline as a function of time. Inset, Average of $10 \mathrm{fEPSPs}$ taken during the baseline period (1) and 55-60 min after DHPG treatment (2). Calibration: $0.5 \mathrm{mV}, 5 \mathrm{~ms}$. B, C, Pretreatment with the protein synthesis inhibitor anisomycin $(25 \mu \mathrm{M})$ reduced DHPG-induced LTD in WT mice $\left(\boldsymbol{B} ;\right.$ Veh; $n=11$ slices; anisomycin; $n=9 ; p<0.001$; two-way ANOVA; Sidak's post hoc tests) but has no effect on LTD in mGlu $5^{R / R}$ mice $\left(\boldsymbol{C} ;\right.$ Veh; $n=11$; anisomycin; $n=10$; not significant). $\boldsymbol{D}$, Low-frequency, $1 \mathrm{~Hz}$, presynaptic stimulation of Schaffer collaterals induces robust LTD in slices from WT ( $n=9$ slices), but not $\mathrm{mGlu} 5^{R / R}$ mice $\left(n=14 ; p<0.01 ; t\right.$ test). $\boldsymbol{E}$, There were no genotypic differences in the effect of mGlu5 blockade (MPEP; $10 \mu \mathrm{m} ; 1 \mathrm{~h}$ ) on fEPSP slopes $\left(\mathrm{WT} ; n=6 ; \mathrm{mGlu} 5^{R / R ;} n=7\right)$.

mGlu5 $5^{R / R}$ hippocampal slices, basal levels of APP and Map1B were slightly, but not significantly, elevated and DHPG stimulation failed to increase their levels (Fig. 4H). We were also unable to detect elevated MAP $1 \mathrm{~b}(100 \pm 5 \%$ of WT; $n=4$ mice $)$ or APP ( $n=92 \pm 5 \%$ of WT; $n=3$ mice; data not shown) in fresh hippocampal lysates from mGlu $5^{R / R}$ mice. Therefore, selective disruption of mGlu5-Homer mimics the distinct alterations of Group1 mGluR signaling pathways to translational control as observed in the Fmr1 KO and inhibits Group1 mGluR-induced translation of FMRP target mRNAs (see Fig. 8).

\section{Protein synthesis-dependent mGluR-LTD is deficient in} mGlu5 $5^{R / R}$ mice

One functional consequence of Group $1 \mathrm{mGluR}$-induced protein synthesis is an LTD of excitatory synaptic transmission (mGluRLTD) in the CA1 region of the hippocampus (Davidkova and Carroll, 2007; Park et al., 2008; Waung et al., 2008). Because Group $1 \mathrm{mGluR}$ activation fails to induce new protein synthesis in
mGlu5 $5^{R / R}$ hippocampal slices, mGluR-LTD in mGlu $5^{R / R}$ mice may be reduced or absent. To test this possibility, mGluR-LTD was measured using extracellular recordings of population EPSPs or field potentials in area CA1 of acute hippocampal slices from WT and mGlu $5^{R / R}$ mice. Brief application of DHPG $(100 \mu \mathrm{M} ; 5$ min) induced an LTD of field potential slope in slices from WT mice ( $72 \pm 3 \%$ of pre-DHPG baseline; $n=14$ slices). In slices from $m G l u 5^{R / R}$ mice, the magnitude of DHPG-induced LTD was reduced ( $84 \pm 4 \%$ of baseline, $n=11$ slices; $p<0.05$; Fig. $5 A$ ). Because Group $1 \mathrm{mGluR}$ activation in $\mathrm{mGlu} 5^{R / R}$ slices does not activate translation, we hypothesized that any remaining mGluRLTD in mGlu $5^{R / R}$ slices would be independent of protein synthesis. To test this possibility, we examined effects of the protein synthesis inhibitor anisomycin $(25 \mu \mathrm{M})$ on DHPG-induced LTD in slices prepared from WT and mGlu $5^{R / R}$ mice. In WT slices, anisomycin reduced the magnitude of mGluR-LTD (Fig. 5B), whereas mGluR-LTD in slices from $m G l u 5^{R / R}$ mice was unaffected (Fig. 5C). These results are consistent with a deficit in 
A

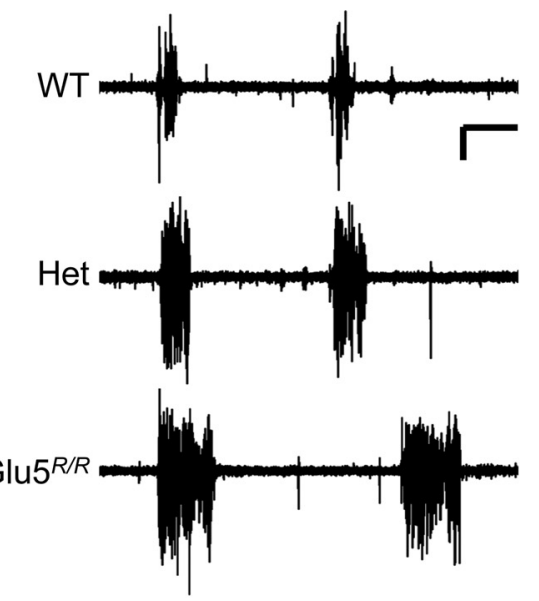

B

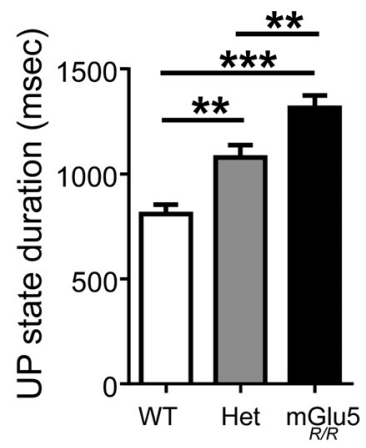

C

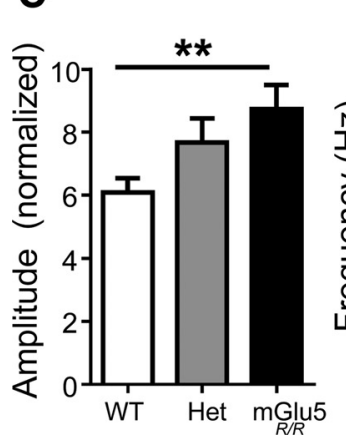

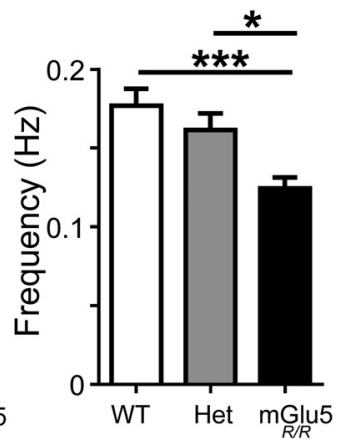
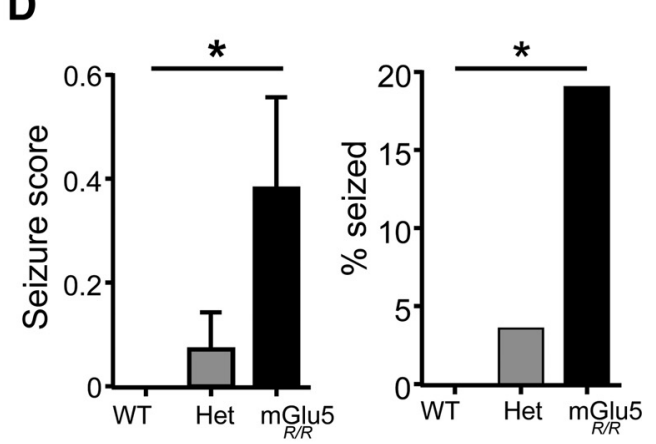

Figure 6. Disruption of mGlu5-Homer interactions is sufficient to mimic neocortical hyperexcitability and audiogenic seizures observed in $F m r 1 \mathrm{KO}$ mice. $\boldsymbol{A}, \boldsymbol{B}$, The $\mathrm{mGlu5F}>\mathrm{R}$ mutation dose-dependently increases spontaneous UP state duration. $A$, Representative extracellular multiunit recordings of spontaneous, persistent activity or UP states from layer 4 of acute somatosensory neocortical slices from each genotype. Calibration: $50 \mu \mathrm{V}, 1 \mathrm{~s}$. B, Group data of average UP state duration in WT, Het, and mGlu5 $5^{R / R}$ littermates (WT, $n=29$ slices; Het, $n=14 ; \mathrm{mGlu} 5^{R / R}, n=18$; ANOVA; Tukey post hoc). C, The average amplitude (normalized to baseline) of UP states is increased in $\mathrm{mGlu} 5^{R / R}$, but UP states occur less frequently (ANOVA; Tukey post hoc). $\boldsymbol{D}$, The $\mathrm{mGlu5F}>\mathrm{R}$ mutation increases the incidence and severity of audiogenic seizures as assessed by seizures score and by percentage mice that seized (described in Materials and Methods) $(N=27, N=28$, and $N=21$ for WT, Het, and mGlu5 ${ }^{R / R}$ littermates, respectively). Score: ANOVA; Tukey multiple-comparison test; percentage seized: Fisher's exact test. ${ }^{*} p<0.05 .{ }^{* *} p<0.01 .{ }^{* * *} p<0.001$.

agonist-induced translational activation in $\mathrm{mGlu} 5^{R / R}$ mice. In Fmrl KO and mGlu5 $5^{R / R}$ mice, LTD is independent of new protein synthesis (Hou et al., 2006; Nosyreva and Huber, 2006). However, in Fmr1 KO, mGluR-LTD is robust and often enhanced (Huber et al., 2002; Nosyreva and Huber, 2006), which is not mimicked by the $\mathrm{mGlu} 5^{R / R}$ mouse.

To determine whether there is a selective deficit in mGlu5dependent forms of synaptic plasticity in mGlu $5^{R / R}$ mice, we examined LTD induced by low-frequency $(1 \mathrm{~Hz})$ stimulation of Schaffer collaterals, which requires activation of NMDA receptors (NMDAR-LTD). NMDAR-LTD is independent of mGlu1/ mGlu5 and new protein synthesis (Huber et al., 2000). Surprisingly, NMDAR-LTD, like mGluR-LTD, was reduced in mGlu $5^{R / R}$ mice ( $84 \pm 3 \%$ of baseline, $n=11$; Fig. $5 D$ ) compared with WT littermates ( $72 \pm 4 \%$ of baseline, $n=11 ; p<0.01$; Fig. $5 D)$. A reduction in both NMDAR- and mGluR-LTD in mGlu $5^{R / R}$ mice suggested either a general deficit in LTD induction mechanisms or LTD may be saturated, by constitutively active mGlu5, which occludes induction of LTD in response to DHPG or $1 \mathrm{~Hz}$ stimulation. If so, then treatment of mGlu $5^{R / R}$ slices with MPEP may reverse any spontaneous synaptic depression caused by constitutive mGlu5 and result in potentiation of synaptic transmission. In contrast to this idea, a $1 \mathrm{~h}$ treatment of MPEP $(10 \mu \mathrm{M})$ caused a slight depression of synaptic transmission in both WT and mGlu $5^{R / R}$ slices (Fig. $5 E$ ). These results suggest a deficit in both NMDAR-dependent and mGluR-LTD induction mechanisms in mGlu ${ }^{R / R}$ slices. The deficit in NMDAR- dependent LTD may be a result of the known inhibition of NMDAR function that results from direct binding of mGlu5 to GluN1 when it is not in a long Homer scaffold (Moutin et al., 2012).

\section{mGlu $5^{R / R}$ mice display sensory neocortical circuit} hyperexcitability, audiogenic seizures, and abnormal sensorimotor gating

FXS patients and Fmrl KO mice exhibit sensory hypersensitivity, epilepsy, and/or audiogenic seizures indicative of hyperexcitable sensory circuits (Rotschafer and Razak, 2014; Contractor et al., 2015). In the sensory neocortex of Fmrl KO mice, in acute slices or in vivo, circuit hyperexcitability is observed by prolonged spontaneously occurring persistent activity, or UP, states (Hays et al., 2011). UP states represent a normal physiological rhythm generated by recurrent inhibitory and excitatory synaptic circuits and is observed in alert and slow-wave sleep states in vivo as well as in neocortical slices (Haider and McCormick, 2009). Genetic or pharmacological reduction of mGlu5 activity or deletion of Hla rescues prolonged UP states in Fmrl KO mice (Hays et al., 2011; Ronesi et al., 2012). To determine whether selective disruption of mGlu5-Homer interactions is sufficient to cause hyperexcitability, we measured spontaneously occurring UP states in acute somatosensory, barrel cortex slices from WT, Het and mGlu5 ${ }^{R / R}$ mice using extracellular multiunit recordings (Sanchez-Vives and McCormick, 2000). Slices prepared from mGlu5 $^{R / R}$ mice displayed long duration UP states $(1315 \pm 59.1$ 
A

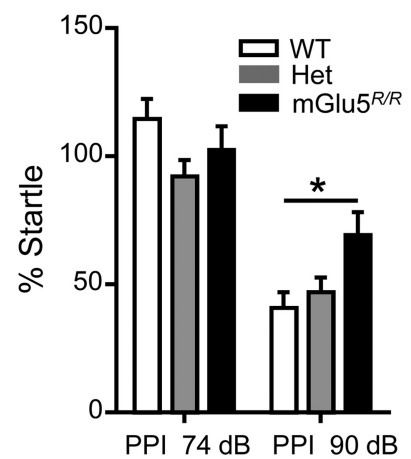

C

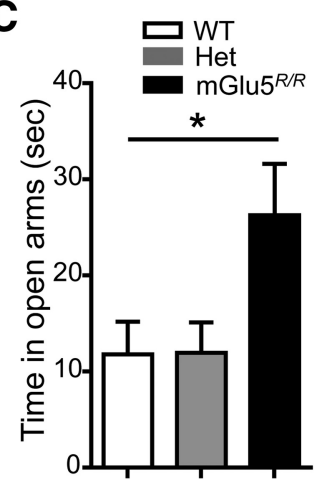

E

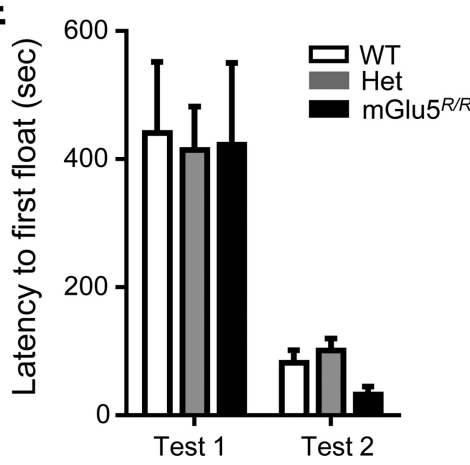

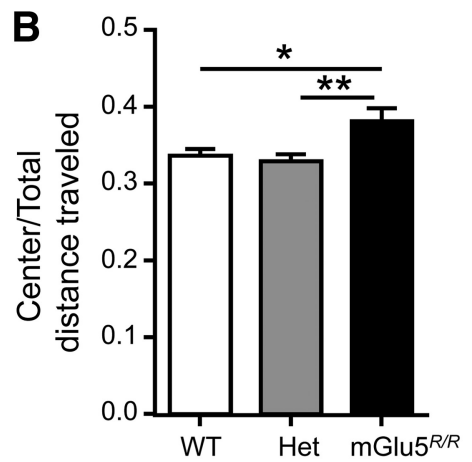

D

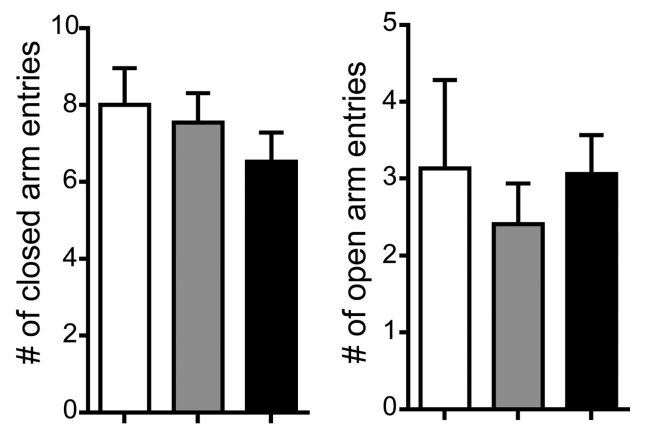

$\mathbf{F}$

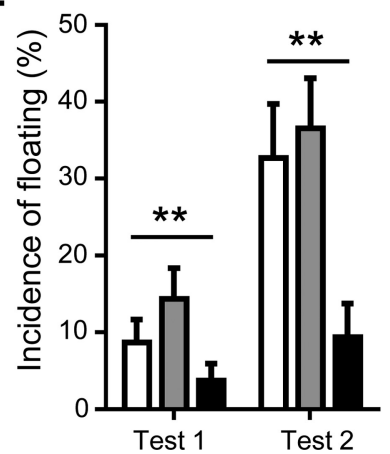

Figure 7. $\mathrm{mGlu} 5^{R / R}$ mice have impaired sensorimotor gating, reduced nonsocial anxiety, and an antidepressant phenotype. $A$, PPI of startle amplitude, measured by the percent inhibition of the startle to $110 \mathrm{~dB}$ tone when preceded by a $90 \mathrm{~dB}$ prepulse, is reduced in $\mathrm{mGlu} 5^{R / R}$ mice compared with WT controls $\left(N=20, N=16\right.$, and $N=13$ for WT, Het, and $\mathrm{mGlu} 5^{R / R}$ littermates, respectively). Prepulse effect: $F_{(1,43)}=117.48, p<0.0001$; genotype $\times$ prepulse: $F_{(2,43)}=4.52, p=0.02$. Startle amplitude at 74 or $90 \mathrm{~dB}$ was not different between genotypes. Data are mean \pm SEM percent inhibition of the $110 \mathrm{~dB}$ startle amplitude by the $74 \mathrm{~dB}$ and the $90 \mathrm{~dB}$ prepulse intensities. ${ }^{*} p<0.05$ versus WT (LSD post hoc tests). ${ }^{* *} p<0.01$. $B, 0$ pen field activity, measured as a ratio of the distance traveled in the center to total distance traveled in an open arena, was increased in $\mathrm{mGlu} 5^{R / R}$ mice compared with WT or Het mice $\left(F_{(2,82)}=5.376, p=0.006\right.$; Dunnet's post hoc tests) $(N=$ $19, N=44$, and $N=22$ for WT, Het, and mGlu5 $5^{R / R}$ littermates, respectively). $C$, mGlu5 $5^{R / R}$ mice spent more time in the open arms as measured by seconds or percentage of total time in the maze $\left(N=15, N=22\right.$, and $N=17$ for WT, Het, and $\mathrm{mGlu} 5^{R / R}$ littermates, respectively). Sex effect: $F_{(1,48)}=6.14, p=0.02$; genotype effect: $F_{(2,48)}=3.45, p=0.04$; interaction: $p=0.21 . \boldsymbol{D}$, Number of entries into closed or open arms of an elevated plus maze were not different between genotypes. $\boldsymbol{E}$, The latency to first float in the Porsolt Swim Test was not different among genotypes. $\boldsymbol{F}$, The percentage of incidence of floating as scored in the first and second swim sessions was reduced in mGlu5 $5^{R / R}$ mice $\left(N=15, N=22\right.$, and $N=17$ for WT, HET, and mGlu5 ${ }^{R / R}$ littermates, respectively). Genotype effect: $F_{(2,49)}=5.52, p=0.007$; no interactions with the genotype factor: $p>0.20$.

ms, $n=26$ slices), equivalent to what we have observed in Fmr1 KO mice (Hays et al., 2011); UP state duration in Het slices was intermediate (1079 $\pm 57.6 \mathrm{~ms}, n=22)$ but still longer than WT $(809.2 \pm 45.0 \mathrm{~ms}, n=21$; Fig. $6 A, B)$. Another indicator of hyperexcitability in $\mathrm{mGlu} 5^{R / R}$ slices is the observed increased amplitude of UP states, which is a course indicator of the firing frequency of active neurons (Fig. $6 \mathrm{C}$ ). The frequency of UP states is less in $\mathrm{mGlu}^{R / R}$ slices (Fig. 6C), as previously observed in Fmr1 $\mathrm{KO}$ (Hays et al., 2011) and is likely due to the known inverse relationship between UP state duration and frequency (SanchezVives and McCormick, 2000). Because $m G l u 5^{R / R}$ slices display a reduced frequency of long duration UP states, the percentage of time in an UP state was similar across genotypes (WT; $14 \pm 1 \%$; $n=21 ;$ Het $17 \pm 1 \% ; n=22 ;$ mGlu $\left.^{R / R} ; 16 \pm 1 \% ; n=26\right)$. These data indicate that mGlu5-Homer interactions dose-dependently regulate neocortical circuit hyperexcitability and disrupted mGlu5-Homer is sufficient to mimic the long UP states observed in the Fmr1 KO mice.

A behavioral manifestation of sensory circuit hyperexcitability in the Fmr1 KO mouse is audiogenic seizures. Genetic deletion of mGlu5 and $\mathrm{H} 1 \mathrm{a}$ reduces, but does not completely rescue, audiogenic seizures in the Fmr1 KO, suggesting that disrupted mGlu5-Homer scaffolds contribute to seizures (Dölen et al., 2007; Ronesi et al., 2012). In support of this idea, mGlu5 ${ }^{R / R}$ mice displayed an increased seizure score $(0.38 \pm 0.18$; see Materials and Methods) and an increased incidence of seizures 
(4 of 17 mice; $p<0.01$ ); compared with WT mice (0 of 27 mice; Fig. 6D).

A consequence of abnormal sensory function in FXS and Fmr1 KO mice may be an abnormal acoustic startle or sensorimotor processing, where a weak auditory prepulse attenuates subsequent responses to a loud startling noise. Individuals with FXS and Fmr $1 \mathrm{KO}$ mouse are commonly reported to have altered prepulse inhibition (PPI) of either whole-body startle or eyeblink (de Vrij et al., 2008; Chen et al., 2011; Levenga et al., 2011). To determine whether mGlu ${ }^{R / R}$ also has alterations in sensorimotor processing, PPI of acoustic startle was measured in mice at 5-7 weeks of age (Szumlinski et al., 2005). The capacity of a prepulse to inhibit the startle response to the $110 \mathrm{~dB}$ tone was intensity-dependent and also depended also upon genotype (prepulse effect: $F_{(1,43)}=117.48, p<0.0001$; genotype $\times$ prepulse: $\left.F_{(2,43)}=4.52, p=0.02\right)$. As illustrated in Figure $7 A$, while the 74 $\mathrm{dB}$ prepulse was ineffective at reducing startle, the $90 \mathrm{~dB}$ prepulse reduced startle amplitude in all genotypes, with $\mathrm{mGlu} 5^{R / R}$ mice exhibiting significantly less PPI, compared with both WT and Het animals. Together, these data indicate that the $\mathrm{mGlu}^{R / R}$ mouse mimics the hyperexcitability of sensory circuits and deficits in sensorimotor gating observed in the Fmrl KO, suggesting a role for mGlu5-Homer in sensory function and dysfunction associated with FXS.

\section{mGlu5 ${ }^{\mathrm{R} / \mathrm{R}}$ mice mimic an "anxiolytic" and "antidepressant" phenotype of Fmr1 KO mice}

A commonly reported behavioral phenotype of the Fmr1 KO mice is a reduced "nonsocial" anxiety as measured by increased time in the center of a lit open field and increased time or entries into the open arms of an elevated plus maze compared with WT littermates (Hayashi et al., 2007; Liu and Smith, 2009; Yuskaitis et al., 2010; Jung et al., 2012), which is reversed by mGlu5 activity blockade (Yan et al., 2005; Busquets-Garcia et al., 2013). Similar to Fmr1 $\mathrm{KO}$ mice, $\mathrm{mGlu} 5^{R / R}$ mice traveled a greater distance in the center when measured as a ratio of the total distance in an open field exploration test ( $\operatorname{sex}$ effect: $F_{(1,79)}=0.56, p=0.45$; genotype effect: $F_{(2,79)}=6.34, p=0.0028$; interaction: $p=0.21$ ). Combining genders revealed a difference in the center/total distance traveled between $\mathrm{mGlu} 5^{R / R}(0.381 \pm 0.017 ; n=22)$ and WT $(0.336 \pm 0.009 ; N=19 ; p<0.05)$ or Het $(0.329 \pm 0.009 ; N=$ $44 ; p<0.01$; Fig. $7 B$ ). There was no effect of genotype on total distance traveled indicating that the mGlu5 $5^{R / R}$ are not hyperactive (WT; $5137 \pm 274.2 \mathrm{~cm}$; Het; $5479 \pm 235 \mathrm{~cm}$; mGlu5 ${ }^{\mathrm{R} / \mathrm{R}}$; $5710 \pm 381.6 \mathrm{~cm}$; not significant). To examine for genotypic differences in another measure of anxiety, a separate cohort of mGlu $5^{R / R}$ mice were tested for their willingness to explore the open arms of an elevated plus maze during a 5 min test session. mGlu $5^{R / R}$ mice spent more time (in seconds) and percentage time in the open arms during the $5 \mathrm{~min}$ test session, relative to both WT and HET animals (Fig. $7 C$ ) (sex effect: $F_{(1,48)}=6.14$, $p=0.02$; genotype effect: $F_{(2,48)}=3.45, p=0.04$; interaction: $p=$ $0.21)$. The number of closed arm entries served to index general locomotor activity and were not different between genotypes (Fig. 7D).

In addition to anxiety, Homer has been implicated in regulation of emotionality and depression-like behaviors (Szumlinski et al., 2005). Anxiety and depression behaviors are also correlated in some rodent models (Overstreet et al., 1992; Hinojosa et al., 2006). Consistent with a reduced anxiety phenotype, Fmr1 KO mice display reduced floating or immobility in the Porsolt forced swim test, a well-established test of "behavioral despair" and antidepressant efficacy (Porsolt et al., 1977; Uutela et al., 2014). To
Table 1. Summary of $F m r 1 \mathrm{KO}$ phenotypes tested for mimic or rescue by manipulation of mGlu5-Homer scaffolds ${ }^{a}$

\begin{tabular}{|c|c|c|}
\hline Fmr1 K0 phenotype & $\begin{array}{l}\text { Rescued with } \\
\text { H1a deletion }{ }^{b}\end{array}$ & $\begin{array}{l}\text { Mimicked in } \\
\text { mGlus } 5^{R / R}\end{array}$ \\
\hline Decreased mGlu5-Homer scaffolds & $x$ & $x$ \\
\hline $\begin{array}{l}\text { Decreased mGlu5 association with postsynaptic } \\
\text { density }\end{array}$ & NT & $x$ \\
\hline $\begin{array}{l}\text { Enhanced, } m \text { Glu5-dependent protein synthesis } \\
\text { rates and translation initiation complexes }\end{array}$ & $x$ & $x$ \\
\hline $\begin{array}{l}\text { Enhanced, mGlu5-dependent activation of ERK } \\
\text { and mTORC1 signaling pathways }\end{array}$ & NT & $x$ \\
\hline $\begin{array}{l}\text { Deficient DHPG-induced activation of ERK and } \\
\text { mTORC1 signaling }\end{array}$ & $x$ & $x$ \\
\hline Enhanced DHPG-induced phosphorylation of EF2 & $x$ & $X$ \\
\hline Prolonged neocortical UP states & X & $x$ \\
\hline Audiogenic seizures & Partial & Partial \\
\hline Reduced PPI & NT & $X$ \\
\hline Increased open field activity & $x$ & $x$ \\
\hline Increased open arms in T-maze & NT & $x$ \\
\hline Decreased floating in Porsolt swim test & NT & $X$ \\
\hline Enhanced protein levels of FMRP target mRNAs ${ }^{c}$ & No & No \\
\hline $\begin{array}{l}\text { Deficient DHPG-induced increase in protein } \\
\text { levels of FMRP target mRNAs }{ }^{c}\end{array}$ & No & $x$ \\
\hline Enhanced mGluR-LTD magnitude ${ }^{c}$ & No & No \\
\hline Protein synthesis-independent mGluR-LTD ${ }^{c}$ & No & $x$ \\
\hline
\end{tabular}

determine whether $\mathrm{mGlu} 5^{R / R}$ mice also displayed such an antidepressant phenotype, mice were assessed for their latency to float and number of floats. Mice were exposed to a pool for 15 min (Test 1) and then tested $24 \mathrm{~h}$ later in a 5 min swim session (Test 2; Fig. $7 E, F$ ). Behavior was scored every $30 \mathrm{~s}$ by an experimenter blind to the genotype of the animals. There were no sex differences in latency or numbers of floats; thus, data from male and female mice were combined for analysis. As illustrated in Fig. $7 E$, all genotypes exhibited the predicted decrease in their latency to first exhibit floating behavior across the two test sessions, indicative of intact recall of emotional memory (test effect: $F_{(1,49)}=$ $130.36, p<0.0001)$ and $\mathrm{mGlu} 5^{R / R}$ mice exhibited a trend toward the shortest latency to first float on Test 1 . However, $\mathrm{mGlu} 5^{R / R}$ mice exhibited less floating behavior during both Test 1 and 2 swim sessions compared with WT and Het mice (genotype effect: $F_{(2,49)}=5.52, p=0.007$; no interactions with the genotype factor, $p>0.20)$. Together, these data indicate that the $\mathrm{mGlu} 5^{R / R}$ display both an "anxiolytic" and "antidepressant" behavioral phenotype and mimic such behaviors observed in Fmrl KO mice.

\section{Discussion}

Here we demonstrate that mutation of a single amino acid in the Homer binding domain of mGlu5 is sufficient to mimic many of the biochemical, neurophysiological, and behavioral phenotypes of a neurodevelopmental disorder in mice (Table 1). This work, together with our findings that $\mathrm{Hla}$ deletion rescues these same phenotypes in Fmrl KO mice, strongly implicates disrupted mGlu5-Homer interactions in the pathophysiology of FXS. Homer has many binding partners, and the mGlu $5^{R / R}$ mice reveal the contribution of mGlu5-Homer interactions to brain function and behavior. The mGlu5F $>\mathrm{R}$ mutation has no effect on FMRP levels but is sufficient to mimic many phenotypes of FXS. mGlu $1 / 5$ dysfunction is implicated in other causes of autism and intellectual disability, suggesting a general role for mGlu1/5Homer binding in these disorders (Auerbach et al., 2011; Baud- 


\section{A Wildtype: Low basal signaling by mGlu5}

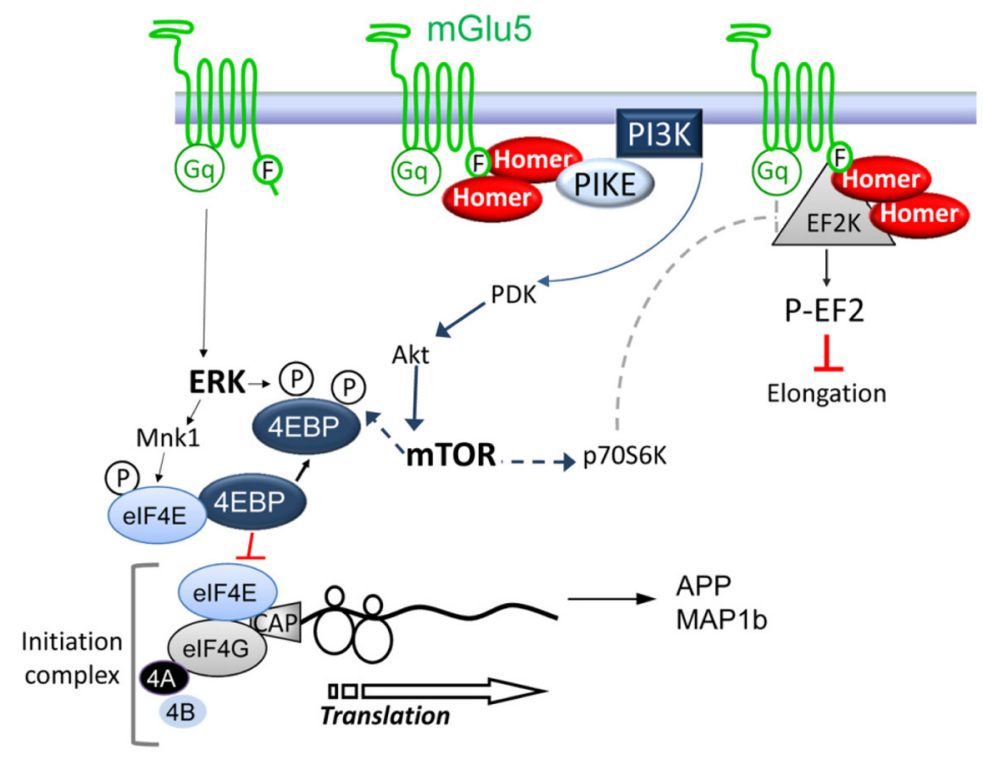

\section{B mGlu5 $5^{R / R}$ : High basal or constitutive $\left(^{*}\right) \mathrm{mGlu} 5$ signaling}

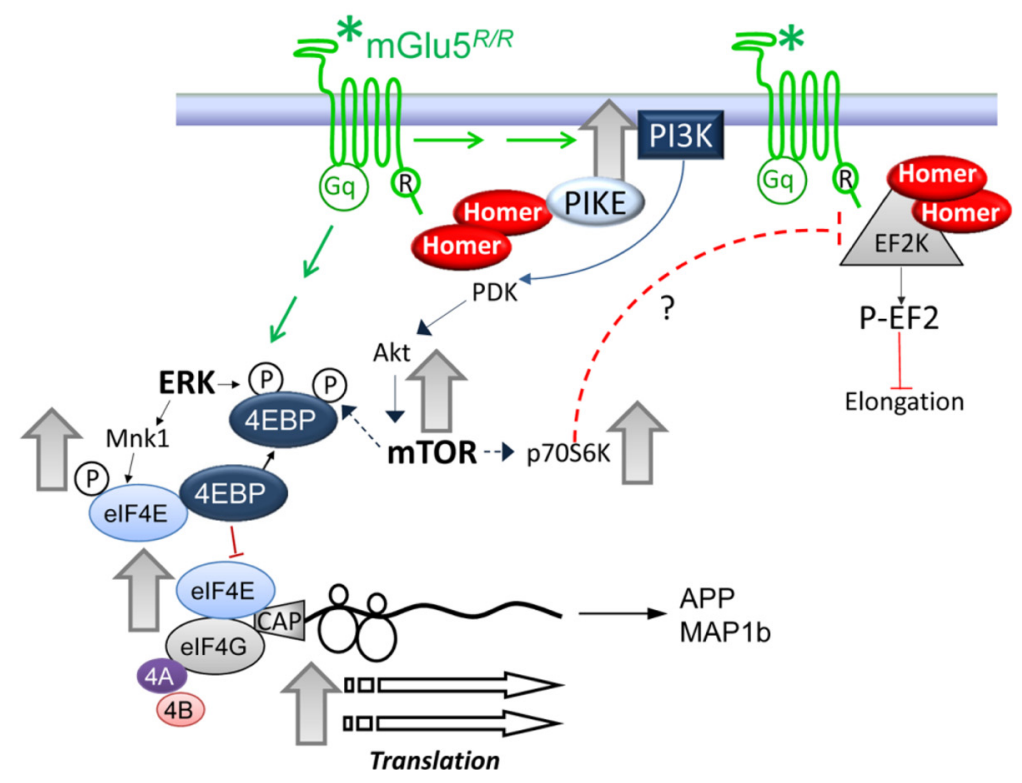

Figure 8. Working model of the role of Homer binding to $\mathrm{mGlu} 5$ in signaling pathways to translation initiation and elongation in WT $(\boldsymbol{A})$ and $\mathrm{mGlu5R/R}(\boldsymbol{B})$ mice as considered in the Discussion.

ouin et al., 2012; Silverman et al., 2012; Ebrahimi-Fakhari and Sahin, 2015; Tian et al., 2015). Our findings also reveal the consequences of a "free" mGlu5, or one that is not in a long-Homer scaffold, which is relevant to normal brain function under conditions of experience and activity that disrupt mGlu5-Homer interactions, such as induction of Hla (Brakeman et al., 1997; Guo et al., 2015).

Surprisingly, mGlu1 $\alpha$-Homer binding was reduced in $m G l u 5^{R / R}$ mice, which is likely an indirect effect of heterodimerization of mGlu1 $\alpha$ with mGlu5 (Beqollari and Kammermeier, 2010; Doumazane et al., 2011). Enhanced ERK, mTORC1 signaling and translation rates in $\mathrm{mGlu} 5^{R / R}$ mice were MPEP-sensitive, impli- cating mGlu5. However, the inability of DHPG, a mGlu1/5 agonist, to activate signaling suggests deficits in mGlul function. Interestingly, inhibition of mGlu1 reduces some Fmr1 KO phenotypes, suggesting a role for constitutively active mGlu1 (Thomas et al., 2011, 2012).

\section{Disrupted Homer-mGlu5 interactions results in constitutive mGlu5 signaling to translational initiation factors and translation rates}

Fmr1 KO mice display enhanced, MPEPsensitive, protein synthesis rates and hyperactivation of PI3K-mTORC1 and ERK (Gross et al., 2010; Osterweil et al., 2010; Sharma et al., 2010; Ronesi et al., 2012). Because FMRP suppresses translation of its mRNA targets (Bassell and Warren, 2008), elevated protein synthesis rates in Fmr1 KO may result directly from loss of this suppression. The mGlu5F $>\mathrm{R}$ mutation is sufficient to cause enhanced mGlu5 and ERK-dependent translation rates, translation initiation complexes, and hyperactivity of the ERK and mTORC1 pathways without affecting FMRP levels. $\mathrm{Hla}$ deletion in Fmr $1 \mathrm{KO}$ restores mGlu5Homer, protein synthesis rates, and translation initiation complexes (Ronesi et al., 2012), suggesting that enhanced protein synthesis rates are due to constitutively active mGlu5 driving translation control pathways and not a direct effect of FMRP on global translation rates. We cannot rule out that excess glutamate activation of mGlu5 in mGlu5 $5^{R / R}$ neurons because MPEP also blocks glutamate-activated mGlu5. This would require a NAM selective for constitutively active mGlu5, which, to our knowledge, is not available. Results with NMDAR antagonists indicate that there is not excess glutamateactivated NMDAR signaling to ERK and mTORC1. Although we observed enhanced translation rates in $\mathrm{mGlu} 5^{R / R}$ slices, MAP1b or APP protein levels, mRNA targets of FMRP (Hou et al., 2006; Westmark and Malter, 2007), only showed a trend to increase likely because FMRP levels are normal.

Homer binding to mGlu5 is necessary for mGlu1/5 agonistinduced signaling to translational control, protein synthesis, and LTD

In both mGlu $5^{R / R}$ and Fmr 1 KO mice, DHPG-induced activation of mTORC1 and ERK pathways to translation initiation is deficient (Ronesi and Huber, 2008; Gross et al., 2010; Sharma et al., 2010; Ronesi et al., 2012). Homer binds PIKE, and our findings agree with previous work (Rong et al., 2003) that a Homer-PIKEmGlu5 complex is necessary for agonist-induced PI3K activation. However, the enhanced, MPEP-sensitive, basal activity of PI3KmTORC in mGlu $5^{R / R}$ neurons suggests that Homer binding to 
mGlu5 suppresses constitutive activation of PI3K-mTORC1, which prevents saturation of the pathway and allows agonistinduced activation. Homer binding serves an analogous function for specific ion channels to suppress constitutive activity and allow activation to cell signals (Worley et al., 2007).

In contrast to translation initiation pathways, DHPG-induced P-EF2 is enhanced in Fmrl KO (Ronesi et al., 2012) and mGlu5 ${ }^{R / R}$ neurons. EF2-kinase (EF2K) binds to Homer and directly with mGlu5 (Park et al., 2008). Therefore, Homer binding to mGlu5 may interfere with or inhibit activation of EF2K by mGlu5. Alternatively or in addition, crosstalk between the PI3KmTORC1 pathway and EF2K may mediate this effect. S6K phosphorylates and inhibits EF2K (Kenney et al., 2014). In WT neurons, DHPG activates both EF2K and S6K, but active S6K may then phosphorylate and inhibit activation of EF2K (Fig. 8). In Fmr $1 \mathrm{KO}$ and $\mathrm{mGlu}^{R / R}$ neurons, DHPG fails to activate S6K and thus may fail to inhibit EF2K, resulting in robust P-EF2. Because P-EF2 suppresses translational elongation, enhanced DHPG-induced P-EF2 combined with a deficit in activation of translation initiation in mGlu5 ${ }^{R / R}$ and Fmr1 KO neurons likely mediates the inability of DHPG to induce rapid increases in APP and Maplb and translation-dependent LTD.

In Fmr1 KO and mGlu5 $5^{R / R}$ neurons, uncoupling of mGlu5 from activation of translation machinery results in protein synthesis-independent LTD (Nosyreva and Huber, 2006). However, mGluR-LTD magnitude is enhanced in Fmrl KO slices but reduced in mGlu5 ${ }^{R / R}$. Robust mGluR-LTD may occur in Fmr1 $\mathrm{KO}$, despite the deficit in mGlu5 activation of translation because of enhanced, steady-state levels of MAP1b and Arc protein, FMRP target mRNAs that promote LTD and not abnormal mGlu5/Homer scaffolds (Davidkova and Carroll, 2007; Niere et al., 2012). Consistently, Hla deletion does not rescue the translation independence of mGluR-LTD in Fmrl KO (Ronesi et al., 2012). Furthermore, in $\mathrm{mGlu} 5^{R / R}$, we did not observe reliable increases in basal Arc (data not shown) or MAP1b protein. Surprisingly, NMDAR-dependent LTD is reduced in $\mathrm{mGlu}^{R / R}$ mice in contrast to Fmrl KO. Reduced NMDAR-LTD in mGlu $5^{R / R}$ may be due to inhibition of NMDAR function that results from direct interactions of mGlu5 and GluN1 that occur when mGlu5 is not in a long Homer scaffold (Moutin et al., 2012).

\section{mGlu5-Homer regulate sensory circuit excitability and behavior}

Audiogenic seizures and long UP states in Fmrl KO neocortex are reduced or rescued by reducing mGlu5 (Yan et al., 2005; Dölen et al., 2007; Hays et al., 2011) or H1a deletion (Ronesi et al., 2012), suggesting that hyperexcitability of sensory circuits is mediated by enhanced mGlu5 activity as a result of altered Homer scaffolding. The mGlu5F $>\mathrm{R}$ mutation is sufficient to cause long UP states of similar duration to Fmrl KO (Hays et al., 2011). However, the incidence of audiogenic seizures in $\mathrm{mGlu} 5^{R / R}$ mice (20\%) was lower than Fmr1 KO (60\%-80\%) (Dölen et al., 2007; Ronesi et al., 2012). Similarly, mGlu5 heterozygosity or H1a deletion completely rescue long UP states in Fmr1 KO but only reduce audiogenic seizures incidence (Dölen et al., 2007; Hays et al., 2011; Ronesi et al., 2012). Other mechanisms, independent of mGlu5-Homer, and/or in subcortical regions, may contribute to audiogenic seizures (Contractor et al., 2015).

Prepulse inhibition of whole-body startle is enhanced in Fmr1 $\mathrm{KO}$ mice, but PPI of eye blink is reduced in Fmr1 KO mice and individuals with FXS (de Vrij et al., 2008; Chen et al., 2011). mGlu5 antagonism restores PPI of eye blink in both species (de Vrij et al., 2008; Berry-Kravis et al., 2009; Levenga et al., 2011), suggesting a role for mGlu5 in reduced PPI. In support of this idea, $\mathrm{mGlu}^{R / R}$ and Homer1 $\mathrm{KO}$ mice display reduced PPI to a startling tone (Szumlinski et al., 2005), suggesting that mGlu5Homer binding is essential for normal sensorimotor gating.

\section{mGlu5, Homer, and Fmr1 regulate anxiety and depression} The $\mathrm{mGlu} 5^{R / R}$ mice also mimicked the reduced, nonsocial anxiety and antidepressant behavior reported in Fmrl KO mice (Liu and Smith, 2009; Uutela et al., 2014). In support of a role for mGlu5 and Homer in anxiety-related behaviors in Fmrl KO, mGlu5 antagonism or H1a deletion rescues these behaviors in Fmr1 KO mice (Yan et al., 2005; Ronesi et al., 2012; BusquetsGarcia et al., 2013). mGlu5 and Homer are linked to anxiety and depression-like behaviors in rodents (Palucha-Poniewiera et al., 2013). Importantly, Homer $1 \mathrm{KO}$ mice display enhanced anxiety and depression that are reversed by $\mathrm{Hla}$ expression in prefrontal cortex (Lominac et al., 2005). Together with our results, this suggests that disruption of $\mathrm{mGlu} 5 /$ Homer scaffolds is anxiolytic and reduces depression, and may contribute to these phenotypes in Fmr1 KO mice.

\section{Synaptic Homer scaffolds and autism}

Disrupted Homer synaptic scaffolds may contribute to other related diseases of intellectual disability and autism. Interestingly, forebrains of Angelman syndrome mice (Ube3A maternal deletion) display enhanced mGlu5-Homer interactions as well as enhanced mGluR-LTD (Pignatelli et al., 2014). Autism spectrum disorder-associated mutations are found in Homer, the Homer binding proteins Shank1,2,3, and other proteins in the HomerShank complex, the SAPAPs and Neuroligins (Kelleher et al., 2012; Delorme et al., 2013; De Rubeis et al., 2014). Loss of function mutations in Shank, SAPAP3, and Neuroligin3 results in abnormal mGlu1 or mGlu5 function (Chen et al., 2011; Verpelli et al., 2011; Wan et al., 2011; Baudouin et al., 2012), suggesting that destabilization of mGlu1/5-Homer scaffolds may be a common synaptic etiology of autism spectrum disorder.

\section{References}

Agmon A, Connors BW (1991) Thalamocortical responses of mouse somatosensory (barrel) cortex in vitro. Neuroscience 41:365-379. CrossRef Medline

Ango F, Pin JP, Tu JC, Xiao B, Worley PF, Bockaert J, Fagni L (2000) Dendritic and axonal targeting of type 5 metabotropic glutamate receptor is regulated by homer1 proteins and neuronal excitation. J Neurosci 20: 8710-8716. Medline

Ango F, Prézeau L, Muller T, Tu JC, Xiao B, Worley PF, Pin JP, Bockaert J, Fagni L (2001) Agonist-independent activation of metabotropic glutamate receptors by the intracellular protein Homer. Nature 411:962-965. CrossRef Medline

Ango F, Robbe D, Tu JC, Xiao B, Worley PF, Pin JP, Bockaert J, Fagni L (2002) Homer-dependent cell surface expression of metabotropic glutamate receptor type 5 in neurons. Mol Cell Neurosci 20:323-329. CrossRef Medline

Auerbach BD, Osterweil EK, Bear MF (2011) Mutations causing syndromic autism define an axis of synaptic pathophysiology. Nature 480:63-68. CrossRef Medline

Banko JL, Hou L, Poulin F, Sonenberg N, Klann E (2006) Regulation of eukaryotic initiation factor $4 \mathrm{E}$ by converging signaling pathways during metabotropic glutamate receptor-dependent long-term depression. J Neurosci 26:2167-2173. CrossRef Medline

Bassell GJ, Warren ST (2008) Fragile X syndrome: loss of local mRNA regulation alters synaptic development and function. Neuron 60:201-214. CrossRef Medline

Baudouin SJ, Gaudias J, Gerharz S, Hatstatt L, Zhou K, Punnakkal P, Tanaka KF, Spooren W, Hen R, De Zeeuw CI, Vogt K, Scheiffele P (2012) Shared synaptic pathophysiology in syndromic and nonsyndromic rodent models of autism. Science 338:128-132. CrossRef Medline 
Beqollari D, Kammermeier PJ (2010) Venus fly trap domain of mGluR1 functions as a dominant negative against group I mGluR signaling. J Neurophysiol 104:439-448. CrossRef Medline

Berry-Kravis E, Hessl D, Coffey S, Hervey C, Schneider A, Yuhas J, Hutchison J, Snape M, Tranfaglia M, Nguyen DV, Hagerman R (2009) A pilot open label, single dose trial of fenobam in adults with fragile X syndrome. J Med Genet 46:266-271. CrossRef Medline

Brakeman PR, Lanahan AA, O’Brien R, Roche K, Barnes CA, Huganir RL, Worley PF (1997) Homer: a protein that selectively binds metabotropic glutamate receptors. Nature 386:284-288. CrossRef Medline

Busquets-Garcia A, Gomis-González M, Guegan T, Agustín-Pavón C, Pastor A, Mato S, Pérez-Samartín A, Matute C, de la Torre R, Dierssen M, Maldonado R, Ozaita A (2013) Targeting the endocannabinoid system in the treatment of fragile X syndrome. Nat Med 19:603-607. CrossRef Medline

Carlin RK, Grab DJ, Cohen RS, Siekevitz P (1980) Isolation and characterization of postsynaptic densities from various brain regions: enrichment of different types of postsynaptic densities. J Cell Biol 86:831-845. CrossRef Medline

Chen M, Wan Y, Ade K, Ting J, Feng G, Calakos N (2011) Sapap3 deletion anomalously activates short-term endocannabinoid-mediated synaptic plasticity. J Neurosci 31:9563-9573. CrossRef Medline

Contractor A, Klyachko VA, Portera-Cailliau C (2015) Altered neuronal and circuit excitability in Fragile X syndrome. Neuron 87:699-715. CrossRef Medline

Cozzoli DK, Goulding SP, Zhang PW, Xiao B, Hu JH, Ary AW, Obara I, Rahn A, Abou-Ziab H, Tyrrel B, Marini C, Yoneyama N, Metten P, Snelling C, Dehoff MH, Crabbe JC, Finn DA, Klugmann M, Worley PF, Szumlinski KK (2009) Binge drinking upregulates accumbens mGluR5-Homer2PI3K signaling: functional implications for alcoholism. J Neurosci 29: 8655-8668. CrossRef Medline

Darnell JC, Klann E (2013) The translation of translational control by FMRP: therapeutic targets for FXS. Nat Neurosci 16:1530-1536. CrossRef Medline

Darnell JC, Van Driesche SJ, Zhang C, Hung KY, Mele A, Fraser CE, Stone EF, Chen C, Fak JJ, Chi SW, Licatalosi DD, Richter JD, Darnell RB (2011) FMRP stalls ribosomal translocation on mRNAs linked to synaptic function and autism. Cell 146:247-261. CrossRef Medline

Davidkova G, Carroll RC (2007) Characterization of the role of microtubuleassociated protein 1B in metabotropic glutamate receptor-mediated endocytosis of AMPA receptors in hippocampus. J Neurosci 27:13273-13278. CrossRef Medline

De Rubeis S, He X, Goldberg AP, Poultney CS, Samocha K, Cicek AE, Kou Y, Liu L, Fromer M, Walker S, Singh T, Klei L, Kosmicki J, Shih-Chen F, Aleksic B, Biscaldi M, Bolton PF, Brownfeld JM, Cai J, Campbell NG, et al. (2014) Synaptic, transcriptional and chromatin genes disrupted in autism. Nature 515:209-215. CrossRef Medline

Delorme R, Ey E, Toro R, Leboyer M, Gillberg C, Bourgeron T (2013) Progress toward treatments for synaptic defects in autism. Nat Med 19:685694. CrossRef Medline

de Vrij FM, Levenga J, van der Linde HC, Koekkoek SK, De Zeeuw CI, Nelson DL, Oostra BA, Willemsen R (2008) Rescue of behavioral phenotype and neuronal protrusion morphology in Fmrl KO mice. Neurobiol Dis 31:127-132. CrossRef Medline

Dölen G, Osterweil E, Rao BS, Smith GB, Auerbach BD, Chattarji S, Bear MF (2007) Correction of fragile X syndrome in mice. Neuron 56:955-962. CrossRef Medline

Doumazane E, Scholler P, Zwier JM, Trinquet E, Rondard P, Pin JP (2011) A new approach to analyze cell surface protein complexes reveals specific heterodimeric metabotropic glutamate receptors. FASEB J 25:66-77. CrossRef Medline

Dutch-Belgian Fragile X Consortium (1994) Fmrl knockout mice: a model to study fragile X mental retardation. Cell 78:23-33. CrossRef Medline

Ebrahimi-Fakhari D, Sahin M (2015) Autism and the synapse: emerging mechanisms and mechanism-based therapies. Curr Opin Neurol 28:91102. CrossRef Medline

English JD, Sweatt JD (1996) Activation of p42 mitogen-activated protein kinase in hippocampal long term potentiation. J Biol Chem 271:2432924332. CrossRef Medline

Gabel LA, Won S, Kawai H, McKinney M, Tartakoff AM, Fallon JR (2004) Visual experience regulates transient expression and dendritic localiza- tion of fragile X mental retardation protein. J Neurosci 24:10579-10583. CrossRef Medline

Gibson JR, Bartley AF, Hays SA, Huber KM (2008) Imbalance of neocortical excitation and inhibition and altered UP states reflect network hyperexcitability in the mouse model of fragile X syndrome. J Neurophysiol 100: 2615-2626. CrossRef Medline

Giuffrida R, Musumeci S, D'Antoni S, Bonaccorso CM, Giuffrida-Stella AM, Oostra BA, Catania MV (2005) A reduced number of metabotropic glutamate subtype 5 receptors are associated with constitutive homer proteins in a mouse model of fragile X syndrome. J Neurosci 25:8908-8916. CrossRef Medline

Gkogkas CG, Khoutorsky A, Cao R, Jafarnejad SM, Prager-Khoutorsky M, Giannakas N, Kaminari A, Fragkouli A, Nader K, Price TJ, Konicek BW, Graff JR, Tzinia AK, Lacaille JC, Sonenberg N (2014) Pharmacogenetic inhibition of eIF4E-dependent Mmp9 mRNA translation reverses fragile X syndrome-like phenotypes. Cell Rep 9:1742-1755. CrossRef Medline

Gross C, Nakamoto M, Yao X, Chan CB, Yim SY, Ye K, Warren ST, Bassell G) (2010) Excess phosphoinositide 3-kinase subunit synthesis and activity as a novel therapeutic target in fragile X syndrome. J Neurosci 30:1062410638. CrossRef Medline

Guo W, Ceolin L, Collins KA, Perroy J, Huber KM (2015) Elevated CaMKII $\alpha$ and hyperphosphorylation of Homer mediate circuit dysfunction in a fragile X syndrome mouse model. Cell Rep 13:2297-2311. CrossRef Medline

Haider B, McCormick DA (2009) Rapid neocortical dynamics: cellular and network mechanisms. Neuron 62:171-189. CrossRef Medline

Hayashi ML, Rao BS, Seo JS, Choi HS, Dolan BM, Choi SY, Chattarji S, Tonegawa S (2007) Inhibition of p21-activated kinase rescues symptoms of fragile X syndrome in mice. Proc Natl Acad Sci U S A 104:1148911494. CrossRef Medline

Hays SA, Huber KM, Gibson JR (2011) Altered neocortical rhythmic activity states in Fmrl KO mice are due to enhanced mGluR5 signaling and involve changes in excitatory circuitry. J Neurosci 31:14223-14234. CrossRef Medline

Heise C, Gardoni F, Culotta L, di Luca M, Verpelli C, Sala C (2014) Elongation factor-2 phosphorylation in dendrites and the regulation of dendritic mRNA translation in neurons. Front Cell Neurosci 8:35. CrossRef Medline

Herbert TP, Tee AR, Proud CG (2002) The extracellular signal-regulated kinase pathway regulates the phosphorylation of $4 \mathrm{E}-\mathrm{BP} 1$ at multiple sites. J Biol Chem 277:11591-11596. CrossRef Medline

Hinojosa FR, Spricigo L Jr, Izídio GS, ${ }^{*}$ Brüske GR, Lopes DM, Ramos A (2006) Evaluation of two genetic animal models in behavioral tests of anxiety and depression. Behav Brain Res 168:127-136. CrossRef Medline

Hou L, Antion MD, Hu D, Spencer CM, Paylor R, Klann E (2006) Dynamic translational and proteasomal regulation of fragile $\mathrm{X}$ mental retardation protein controls mGluR-dependent long-term depression. Neuron 51: 441-454. CrossRef Medline

Hu JH, Park JM, Park S, Xiao B, Dehoff MH, Kim S, Hayashi T, Schwarz MK, Huganir RL, Seeburg PH, Linden DJ, Worley PF (2010) Homeostatic scaling requires group I mGluR activation mediated by Homerla. Neuron 68:1128-1142. CrossRef Medline

Hu JH, Yang L, Kammermeier PJ, Moore CG, Brakeman PR, Tu J, Yu S, Petralia RS, Li Z, Zhang PW, Park JM, Dong X, Xiao B, Worley PF (2012) Presol dynamically regulates group I metabotropic glutamate receptors. Nat Neurosci 15:836-844. CrossRef Medline

Huber KM, Kayser MS, Bear MF (2000) Role for rapid dendritic protein synthesis in hippocampal mGluR-dependent long-term depression. Science 288:1254-1257. CrossRef Medline

Huber KM, Gallagher SM, Warren ST, Bear MF (2002) Altered synaptic plasticity in a mouse model of fragile X mental retardation. Proc Natl Acad Sci U S A 99:7746-7750. CrossRef Medline

Jakkamsetti V, Tsai NP, Gross C, Molinaro G, Collins KA, Nicoletti F, Wang KH, Osten P, Bassell GJ, Gibson JR, Huber KM (2013) Experienceinduced Arc/Arg3.1 primes CA1 pyramidal neurons for metabotropic glutamate receptor-dependent long-term synaptic depression. Neuron 80:72-79. CrossRef Medline

Jung KM, Sepers M, Henstridge CM, Lassalle O, Neuhofer D, Martin H, Ginger M, Frick A, DiPatrizio NV, Mackie K, Katona I, Piomelli D, Manzoni OJ (2012) Uncoupling of the endocannabinoid signalling complex 
in a mouse model of fragile X syndrome. Nat Commun 3:1080. CrossRef Medline

Kelleher RJ 3rd, Govindarajan A, Jung HY, Kang H, Tonegawa S (2004) Translational control by MAPK signaling in long-term synaptic plasticity and memory. Cell 116:467-479. CrossRef Medline

Kelleher RJ 3rd, Geigenmüller U, Hovhannisyan H, Trautman E, Pinard R, Rathmell B, Carpenter R, Margulies D (2012) High-throughput sequencing of mGluR signaling pathway genes reveals enrichment of rare variants in autism. PLoS One 7:e35003. CrossRef Medline

Kenney JW, Moore CE, Wang X, Proud CG (2014) Eukaryotic elongation factor 2 kinase, an unusual enzyme with multiple roles. Adv Biol Regul 55:15-27. CrossRef Medline

Kouser M, Speed HE, Dewey CM, Reimers JM, Widman AJ, Gupta N, Liu S, Jaramillo TC, Bangash M, Xiao B, Worley PF, Powell CM (2013) Loss of predominant Shank3 isoforms results in hippocampus-dependent impairments in behavior and synaptic transmission. J Neurosci 33:1844818468. CrossRef Medline

Lee KM, Coehlo M, McGregor HA, Waltermire RS, Szumlinski KK (2015) Binge alcohol drinking elicits persistent negative affect in mice. Behav Brain Res 291:385-398. CrossRef Medline

Levenga J, Hayashi S, de Vrij FM, Koekkoek SK, van der Linde HC, Nieuwenhuizen I, Song C, Buijsen RA, Pop AS, Gomezmancilla B, Nelson DL, Willemsen R, Gasparini F, Oostra BA (2011) AFQ056, a new mGluR5 antagonist for treatment of fragile X syndrome. Neurobiol Dis 42:311317. CrossRef Medline

Liu ZH, Smith CB (2009) Dissociation of social and nonsocial anxiety in a mouse model of fragile X syndrome. Neurosci Lett 454:62-66. CrossRef Medline

Lominac KD, Oleson EB, Pava M, Klugmann M, Schwarz MK, Seeburg PH, During MJ, Worley PF, Kalivas PW, Szumlinski KK (2005) Distinct roles for different Homer 1 isoforms in behaviors and associated prefrontal cortex function. J Neurosci 25:11586-11594. CrossRef Medline

Michalon A, Sidorov M, Ballard TM, Ozmen L, Spooren W, Wettstein JG, Jaeschke G, Bear MF, Lindemann L (2012) Chronic pharmacological mGlu5 inhibition corrects fragile $\mathrm{X}$ in adult mice. Neuron 74:49-56. CrossRef Medline

Moutin E, Raynaud F, Roger J, Pellegrino E, Homburger V, Bertaso F, Ollendorff V, Bockaert J, Fagni L, Perroy J (2012) Dynamic remodeling of scaffold interactions in dendritic spines controls synaptic excitability. J Cell Biol 198:251-263. CrossRef Medline

Niere F, Wilkerson JR, Huber KM (2012) Evidence for a fragile X mental retardation protein-mediated translational switch in metabotropic glutamate receptor-triggered Arc translation and long-term depression. J Neurosci 32:5924-5936. CrossRef Medline

Nosyreva ED, Huber KM (2006) Metabotropic receptor-dependent longterm depression persists in the absence of protein synthesis in the mouse model of fragile X syndrome. J Neurophysiol 95:3291-3295. CrossRef Medline

Osterweil EK, Krueger DD, Reinhold K, Bear MF (2010) Hypersensitivity to mGluR5 and ERK1/2 leads to excessive protein synthesis in the hippocampus of a mouse model of fragile X syndrome. J Neurosci 30:1561615627. CrossRef Medline

Overstreet DH, Rezvani AH, Janowsky DS (1992) Maudsley reactive and nonreactive rats differ only in some tasks reflecting emotionality. Physiol Behav 52:149-152. CrossRef Medline

Pałucha-Poniewiera A, Wieroñska JM, Brañski P, Burnat G, Chruœcicka B, Pilc A (2013) Is the mGlu5 receptor a possible target for new antidepressant drugs? Pharmacol Rep 65:1506-1511. CrossRef Medline

Park S, Park JM, Kim S, Kim JA, Shepherd JD, Smith-Hicks CL, Chowdhury S, Kaufmann W, Kuhl D, Ryazanov AG, Huganir RL, Linden DJ, Worley PF (2008) Elongation factor 2 and fragile X mental retardation protein control the dynamic translation of Arc/Arg3.1 essential for mGluR-LTD. Neuron 59:70-83. CrossRef Medline

Pignatelli M, Piccinin S, Molinaro G, Di Menna L, Riozzi B, Cannella M, Motolese M, Vetere G, Catania MV, Battaglia G, Nicoletti F, Nisticò R, Bruno V (2014) Changes in mGlu5 receptor-dependent synaptic plasticity and coupling to homer proteins in the hippocampus of Ube3A hemizygous mice modeling angelman syndrome. J Neurosci 34:45584566. CrossRef Medline

Porsolt RD, Le Pichon M, Jalfre M (1977) Depression: a new animal model sensitive to antidepressant treatments. Nature 266:730-732. CrossRef Medline

Proud CG (2007) Signalling to translation: how signal transduction pathways control the protein synthetic machinery. Biochem J 403:217-234. CrossRef Medline

Raab-Graham KF, Haddick PC, Jan YN, Jan LY (2006) Activity- and mTOR-dependent suppression of Kv1.1 channel mRNA translation in dendrites. Science 314:144-148. CrossRef Medline

Roche KW, Tu JC, Petralia RS, Xiao B, Wenthold RJ, Worley PF (1999) Homer $1 \mathrm{~b}$ regulates the trafficking of group I metabotropic glutamate receptors. J Biol Chem 274:25953-25957. CrossRef Medline

Ronesi JA, Huber KM (2008) Homer interactions are necessary for metabotropic glutamate receptor-induced long-term depression and translational activation. J Neurosci 28:543-547. CrossRef Medline

Ronesi JA, Collins KA, Hays SA, Tsai NP, Guo W, Birnbaum SG, Hu JH, Worley PF, Gibson JR, Huber KM (2012) Disrupted Homer scaffolds mediate abnormal mGluR5 function in a mouse model of fragile X syndrome. Nat Neurosci 15:431-440, S1. CrossRef Medline

Rong R, Ahn JY, Huang H, Nagata E, Kalman D, Kapp JA, Tu J, Worley PF, Snyder SH, Ye K (2003) PI3 kinase enhancer-Homer complex couples mGluRI to PI3 kinase, preventing neuronal apoptosis. Nat Neurosci 6:1153-1161. CrossRef Medline

Rotschafer SE, Razak KA (2014) Auditory processing in fragile X syndrome. Front Cell Neurosci 8:19. CrossRef Medline

Sanchez-Vives MV, McCormick DA (2000) Cellular and network mechanisms of rhythmic recurrent activity in neocortex. Nat Neurosci 3:10271034. CrossRef Medline

Scharf SH, Jaeschke G, Wettstein JG, Lindemann L (2015) Metabotropic glutamate receptor 5 as drug target for Fragile X syndrome. Curr Opin Pharmacol 20:124-134. CrossRef Medline

Sharma A, Hoeffer CA, Takayasu Y, Miyawaki T, McBride SM, Klann E, Zukin RS (2010) Dysregulation of mTOR signaling in fragile X syndrome. J Neurosci 30:694-702. CrossRef Medline

Shiraishi-Yamaguchi Y, Furuichi T (2007) The Homer family proteins. Genome Biol 8:206. CrossRef Medline

Silverman JL, Smith DG, Rizzo SJ, Karras MN, Turner SM, Tolu SS, Bryce DK, Smith DL, Fonseca K, Ring RH, Crawley JN (2012) Negative allosteric modulation of the mGluR5 receptor reduces repetitive behaviors and rescues social deficits in mouse models of autism. Sci Transl Med 4:131 ra151. CrossRef Medline

Szumlinski KK, Lominac KD, Kleschen MJ, Oleson EB, Dehoff MH, Schwarz MK, Seeburg PH, Worley PF, Kalivas PW (2005) Behavioral and neurochemical phenotyping of Homer1 mutant mice: possible relevance to schizophrenia. Genes Brain Behav 4:273-288. CrossRef Medline

Szumlinski KK, Ary AW, Lominac KD (2008) Homers regulate druginduced neuroplasticity: implications for addiction. Biochem Pharmacol 75:112-133. CrossRef Medline

Thomas AM, Bui N, Graham D, Perkins JR, Yuva-Paylor LA, Paylor R (2011) Genetic reduction of group 1 metabotropic glutamate receptors alters select behaviors in a mouse model for fragile $\mathrm{X}$ syndrome. Behav Brain Res 223:310-321. CrossRef Medline

Thomas AM, Bui N, Perkins JR, Yuva-Paylor LA, Paylor R (2012) Group I metabotropic glutamate receptor antagonists alter select behaviors in a mouse model for fragile X syndrome. Psychopharmacology (Berl) 219: 47-58. CrossRef Medline

Tian D, Stoppel LJ, Heynen AJ, Lindemann L, Jaeschke G, Mills AA, Bear MF (2015) Contribution of mGluR5 to pathophysiology in a mouse model of human chromosome 16p11.2 microdeletion. Nat Neurosci 18:182-184. CrossRef Medline

Tsai NP, Wilkerson JR, Guo W, Maksimova MA, DeMartino GN, Cowan CW, Huber KM (2012) Multiple autism-linked genes mediate synapse elimination via proteasomal degradation of a synaptic scaffold PSD-95. Cell 151:1581-1594. CrossRef Medline

Tu JC, Xiao B, Yuan JP, Lanahan AA, Leoffert K, Li M, Linden DJ, Worley PF (1998) Homer binds a novel proline-rich motif and links group 1 metabotropic glutamate receptors with IP3 receptors. Neuron 21:717726. CrossRef Medline

Tu JC, Xiao B, Naisbitt S, Yuan JP, Petralia RS, Brakeman P, Doan A, Aakalu VK, Lanahan AA, Sheng M, Worley PF (1999) Coupling of mGluR/ Homer and PSD-95 complexes by the Shank family of postsynaptic density proteins. Neuron 23:583-592. CrossRef Medline

Uutela M, Lindholm J, Rantamäki T, Umemori J, Hunter K, Võikar V, Cas- 
trén ML (2014) Distinctive behavioral and cellular responses to fluoxetine in the mouse model for Fragile X syndrome. Front Cell Neurosci 8:150. CrossRef Medline

Verpelli C, Dvoretskova E, Vicidomini C, Rossi F, Chiappalone M, Schoen M, Di Stefano B, Mantegazza R, Broccoli V, Böckers TM, Dityatev A, Sala C (2011) Importance of Shank3 protein in regulating metabotropic glutamate receptor 5 (mGluR5) expression and signaling at synapses. J Biol Chem 286:34839-34850. CrossRef Medline

Villasana LE, Klann E, Tejada-Simon MV (2006) Rapid isolation of synaptoneurosomes and postsynaptic densities from adult mouse hippocampus. J Neurosci Methods 158:30-36. CrossRef Medline

Wan Y, Feng G, Calakos N (2011) Sapap3 deletion causes mGluR5dependent silencing of AMPAR synapses. J Neurosci 31:16685-16691. CrossRef Medline

Waung MW, Pfeiffer BE, Nosyreva ED, Ronesi JA, Huber KM (2008) Rapid translation of Arc/Arg3.1 selectively mediates mGluR-dependent LTD through persistent increases in AMPAR endocytosis rate. Neuron 59: 84-97. CrossRef Medline

Westmark CJ, Malter JS (2007) FMRP mediates mGluR5-dependent translation of amyloid precursor protein. PLoS Biol 5:e52. CrossRef Medline

Worley PF, Zeng W, Huang G, Kim JY, Shin DM, Kim MS, Yuan JP, Kiselyov $\mathrm{K}$, Muallem S (2007) Homer proteins in $\mathrm{Ca}^{2+}$ signaling by excitable and non-excitable cells. Cell Calcium 42:363-371. CrossRef Medline

Yan QJ, Rammal M, Tranfaglia M, Bauchwitz RP (2005) Suppression of two major Fragile X Syndrome mouse model phenotypes by the mGluR5 antagonist MPEP. Neuropharmacology 49:1053-1066. CrossRef Medline

Yuskaitis CJ, Mines MA, King MK, Sweatt JD, Miller CA, Jope RS (2010) Lithium ameliorates altered glycogen synthase kinase-3 and behavior in a mouse model of fragile X syndrome. Biochem Pharmacol 79:632-646. CrossRef Medline 